medRxiv preprint doi: https://doi.org/10.1101/2020.06.09.20127068; this version posted June 11, 2020. The copyright holder for this preprint (which was not certified by peer review) is the author/funder, who has granted medRxiv a license to display the preprint in perpetuity.

It is made available under a CC-BY-NC-ND 4.0 International license .

\title{
Global RNA-seq identified FBXL8 as a novel E3 ligase which modulates tumor suppressors to promote BRCA advancement
}

Shu-Chun Chang ${ }^{1, \Sigma, *}$, Wayne Hsu², Emily Chia-Yu Sü ${ }^{3,4}$, Chin-Sheng Hung ${ }^{5,6,7, *}$ and Jeak Ling Ding $8,9, \Sigma, *$

${ }^{1}$ The PhD Program for Translational Medicine, College for Medical Science and Technology, Taipei Medical University, Taipei 110, Taiwan

${ }^{2}$ Division of Acute Care Surgery, Department of Surgery, Taipei Medical University Hospital, Taipei 110, Taiwan

${ }^{3}$ Graduate Institute of Biomedical Informatics, College of Medical Science and Technology, Taipei Medical University Hospital, Taipei 110, Taiwan

${ }^{4}$ Clinical Big Data Research Center, Taipei Medical University Hospital, Taipei 110, Taiwan

${ }^{5}$ Division of General Surgery, Department of Surgery, Shuang Ho Hospital, Taipei Medical University, New Taipei City, Taiwan

${ }^{6}$ Division of Breast Surgery, Department of Surgery, Taipei Medical University Hospital, Taipei 110, Taiwan

${ }^{7}$ Division of General Surgery, Department of Surgery, School of Medicine, College of Medicine, Taipei Medical University, Taipei 110, Taiwan

${ }^{8}$ Department of Biological Sciences, National University of Singapore, Singapore 117543

${ }^{9}$ National University of Singapore Graduate School of Integrative Sciences and Engineering, Singapore 119077

${ }^{\Sigma}$ Co-senior authors: $\quad$ sc.chang@tmu.edu.tw dbsdjl@nus.edu.sg

*Co-corresponding authors: sc.chang@tmu.edu.tw hungcs@tmu.edu.tw dbsdjl@nus.edu.sg

Running title: FBXL8-CCND2-IRF5 crosstalk controls BRCA status

Keywords: FBXL8 SCF E3 ubiquitin ligase; CCND2; IRF5; breast cancer (BRCA) and metastasis; pro-tumorigenic microenvironment 
medRxiv preprint doi: https://doi.org/10.1101/2020.06.09.20127068; this version posted June 11, 2020. The copyright holder for this preprint (which was not certified by peer review) is the author/funder, who has granted medRxiv a license to display the preprint in perpetuity.

\begin{abstract}
The initiation and progression of breast cancer (BRCA) is associated with inflammation and immune-overactivation. The E3 ubiquitin ligase is known to subtly balance immune-overactivation and pro-tumorigenesis. Here, by global transcriptional profiling of BRCA patient tissues, we identified a signature expression profile of F-box factors, of which FBXL8 emerged as a novel key component of E3 ligase. Our ex vivo studies $(n=1349)$ indicate that FBXL8 promotes tumorigenesis and its level escalates with BRCA advancement. Knockdown of FBXL8 caused: (i) accumulation of two tumorsuppressors,CCND2 and IRF5, suggesting their collaborative regulation of BRCA status, (ii) intrinsic apoptosis in BRCA, (iii) inhibition of cell migration and invasion and (iv) downregulation of cancer-promoting cytokines/ chemokines; all of these effects curtailed the tumor microenvironment and suppressed cancer progression. Our findings highlight the translational impact of exploiting FBXL8 and its interaction partners (CCND2 and IRF5) for developing anti-cancer strategies and potential therapeutics to limit BRCA progression.
\end{abstract}


medRxiv preprint doi: https://doi.org/10.1101/2020.06.09.20127068; this version posted June 11, 2020. The copyright holder for this preprint (which was not certified by peer review) is the author/funder, who has granted medRxiv a license to display the preprint in perpetuity.

It is made available under a CC-BY-NC-ND 4.0 International license .

\section{Introduction}

Breast cancer (BRCA) is the most common malignancy in women, being responsible for more than 500,000 deaths each year worldwide. In Western countries, BRCA constitutes $25 \%$ of female malignancies $(1,2)$. Increasing evidence suggest that the ubiquitin machinery plays a pivotal role in cancer development and progression $(3,4)$. However, the key factors and underlying mechanisms involved in BRCA are not fully explored. MLN4924 is a newly discovered investigational small molecule inhibitor of NAE (NEDD8 Activating Enzyme), currently under Phase I clinical trial. MLN4924 was reported to inactivate SCF E3 ligase by inhibiting cullin neddylation (5). Cumulative studies have demonstrated that MLN4924 inhibited cancer cell growth, including $\operatorname{BRCA}(6,7)$. Both in vivo and in vitro studies showed that upon stimulation, the SCF E3 ubiquitin machinery can induce dynamic changes to a series of cytokine expression, which favors a pro-tumorigenic microenvironment $(8,9)$. Therefore, there may be vital members of the SCF E3 ubiquitin ligase family, which could drive pro-tumorigenesis. Being the largest family of E3 ubiquitin ligases, the SCF is composed of four components: SKP1, a cullin, an F-box protein, and RBX1 or RBX2. This multimeric complex is responsible for ubiquitination-mediated degradation of target proteins involved in various biological processes (10). A well-regulated SCF E3 ubiquitin ligase maintains homeostasis in cell proliferation and genome stability, hence preventing carcinogenesis (10).

Previously, we demonstrated that SCF (Skp1-cullin-F-box proteins) E3 ubiquitin ligase critically balances immune-overactivation and pro-tumorigenesis $(11,12)$, prompting us to hypothesize a vicious network of chronic inflammation-driven activation of SCF E3 ligase, which probably facilitates ubiquitination-mediated degradation of cancer-modulating factors and also perturbs the pro-tumorigenic cytokines. To test this hypothesis, here we aimed to first elucidate the specific SCF E3 
medRxiv preprint doi: https://doi.org/10.1101/2020.06.09.20127068; this version posted June 11, 2020. The copyright holder for this preprint (which was not certified by peer review) is the author/funder, who has granted medRxiv a license to display the preprint in perpetuity.

It is made available under a CC-BY-NC-ND 4.0 International license.

ligases and their potential pathobiological partners, and then explore their mechanisms in driving BRCA progression, with a view to understanding how the SCF E3 ubiquitin ligases might act as significant risk factors in cancer advancement (13). Since the F-box is responsible for the functional specificity of SCF E3 tetrameric complex (14), we focused our attention on the expression profiles of F-box factors. Notably, there are 71 genes in the human "F-box gene family", including: (1) $21 \mathrm{~F}-$ boxes grouped as leucine-rich repeat protein, (2) $11 \mathrm{~F}$-boxes with WD repeat domain and (3) 39 F-boxes grouped as "others" (15-17).

By ex vivo characterization of the "signature profile" of F-box factors in patients' BRCA tissues, we identified for the first time, a novel F-Box factor, FBXL8, which was significantly upregulated with disease advancement. FBXL8 was found to interact with two tumor-suppressors, CCND2 and IRF5. Knockdown of FBXL8 in BRCA cells resulted in the accumulation of CCND2 and IRF5, concomitant with cancer suppression. CCND2, a member of the D-type cyclins has been implicated in cell cycle regulation, differentiation and malignant transformation, and is seemingly inactivated in human cancers (18). IRF5 is a transcription factor, purported to be a cancersuppressor which regulates apoptosis and immune activation $(19,20)$. Our findings will open new avenues for further translational research on E3 ubiquitin ligase-related regulation and intervention of cancer. We propose that manipulation of FBXL8 and its binding partners could beneficially dampen the pro-tumorigenic microenvironment, and curb metastasis. 
medRxiv preprint doi: https://doi.org/10.1101/2020.06.09.20127068; this version posted June 11, 2020. The copyright holder for this preprint (which was not certified by peer review) is the author/funder, who has granted medRxiv a license to display the preprint in perpetuity.

\section{Results}

\section{Clinicopathological parameters of BRCA patient tissues used for the global RNA sequencing}

Clinical information of five representative BRCA patients with confirmed cancer staging, was obtained retrospectively from the medical records of BioBank, Taipei Medical University. The clinical stages of patients were selected based on tumornode-metastasis (TNM): stage I $(n=1)$, stage II $(n=2)$ and stage III $(n=2)$. The age of the BRCA patients ranged from 38 to 69 years, with a mean of 59 years. The histology type was diagnosed as invasive lobular carcinoma (ILC) or invasive ductal carcinoma (IDC). BRCA resection pathology reports included primary tumor, categories and pathologic lymph node status. Figure $1 \mathrm{~A}$ summarizes the clinicopathological parameters of the BRCA patients.

\section{FBXL8 is significantly upregulated in human primary BRCA tissues.}

To explore the clinical significance of the key components of SCF multimeric complex which might respond to BRCA progression, and to identify the corresponding F-box factors involved, we performed an NGS-based RNA-Seq to profile the gene expression of the F-Box members in human primary breast carcinoma tissues. The five breast carcinoma tissues which have been clinically staged and characterized alongside corresponding normal counterpart tissues, were subjected to global mRNA profiling. We found that several SCF components were overexpressed in BRCA, including SKP1 (S-phase kinase-associated protein 1), SKP2, CUL1 (cullin 1), FBXW7 (F-box/WD repeat-containing protein 7), SAG (Sensitive to apoptosis gene), FBXO4 (F-box only protein 4) and RBX1 (ring-box 1) (Supplementary Figure S1). Red arrow $(\uparrow)$ highlights the upregulation of the identified F-box gene, FBXL8 (Figure 1A). Compared to normal control tissues, the mRNA level of FBXL8 in carcinoma tissues 
medRxiv preprint doi: https://doi.org/10.1101/2020.06.09.20127068; this version posted June 11, 2020. The copyright holder for this preprint (which was not certified by peer review) is the author/funder, who has granted medRxiv a license to display the preprint in perpetuity.

It is made available under a CC-BY-NC-ND 4.0 International license .

was significantly upregulated by up to 7.5 -fold $\left({ }^{*}\right.$, False Discovery Rate, FDR<0.05). Scatter plot (Figure 1B) illustrates quantitative differences in the expression levels of FBXL8 mRNA in individual clinical samples, with 3-fold increase in breast carcinoma (expressed in log2). We found that amongst all 71 F-box family members, FBXL8, a novel F-box factor, was prominently upregulated in breast carcinoma tissues, compared to the corresponding paired normal tissues (FDR<0.05). Consistently, RNASequencing data in TCGA (The Cancer Genome Atlas) showed that the mRNA expression of FBXL8 was significantly upregulated in BRCA tissues (Figure 1C, ${ }^{*}$ $p<0.01)$. Since information on FBXL8 is lacking in literature, we performed sequence alignment of FBXL8 with several mammalian species using Clustal Omega and found that FBXL8 contains highly conserved amino acid sequence amongst mammals (Figure 1D), suggesting its fundamental biological roles.

\section{FBXL8 is upregulated with the advancement of BRCA stages.}

To affirm the RNA-Seq data (Fig. 1) and to further understand the correlation between FBXL8 expression and the clinical status of BRCA patients, we performed qRT-PCR and IHC staining to retrospectively analyze more clinical BRCA tissues (Figure 2). The FBXL8 mRNA profiles of 32 paired samples $(n=64)$ were determined. Supplementary Figure $\mathbf{S 2}$ shows the clinicopathological parameters of the BRCA patient breast tissue samples used for qRT-PCR analysis. Consistently, the mRNA levels of FBXL8 were significantly elevated $(p<0.01)$ in primary BRCA tissues (Figure 2A). The expression levels of FBXL8 correlated significantly $(p<0.01)$ with clinical staging. In addition, SAG (sensitive to apoptosis gene), another important component of SCF E3 ubiquitin ligase, which confers anti-apoptosis and promotes liver cancer $(12,21,22)$, was also significantly upregulated $(p<0.01)$ in all stages of BRCA (Figure 2B). This further corroborates the critical role of the members of SCF E3 ubiquitin ligase in BRCA 
medRxiv preprint doi: https://doi.org/10.1101/2020.06.09.20127068; this version posted June 11, 2020. The copyright holder for this preprint (which was not certified by peer review) is the author/funder, who has granted medRxiv a license to display the preprint in perpetuity.

It is made available under a CC-BY-NC-ND 4.0 International license .

progression. IHC of FBXL8 in 30 paired BRCA tissues $(n=60)$ also showed increase in FBXL8 with disease progression from stages IA to IIA/B to IIIA/B/C (Figure 2C). The clinicopathological parameters of the corresponding tissue sections are shown in Supplementary Figures S3. The expression of both the mRNA and protein of FBXL8 in BRCA tissues were consistently increased by up to 4-fold compared to normal tissues, and the levels in BRCA tissues were found to elevate with the advancement of cancer $(p<0.001)$ (Figure 2D). Clearly, the FBXL8, a newly identified F-box factor is associated with the progression of BRCA. Furthermore, a rise in the ubiquitin protein in BRCA tissues (Figure 2E) also corroborates the significance of the ubiquitin proteasome system (UPS) in BRCA development. Altogether, we have demonstrated simultaneous increases in the levels of FBXL8, SAG and ubiquitin, all of which are functionally related to the UPS protein degradation system, in BRCA formation.

\section{FBXL8 is a novel anti-apoptosis factor in BRCA.}

To elucidate the mechanisms underlying the pathophysiological significance of FBXL8, we performed gene specific-siRNA knockdown of FBXL8 in breast carcinoma cells to assess the potential loss/gain-of-function. We first examined the endogenous levels of FBXL8 in two human BRCA cell lines, including a highly invasive MDA-MB231, a less invasive MCF7, and a control cell line, MCF10A which expresses very low basal level of FBXL8. Prior to knockdown, we observed 23- and 15- folds higher expression of FBXL8 in MCF7 and MDA-MB231, respectively, compared to that of the control MCF10A cells $(p<0.01)$ (Figure 3A). With up to 95\% knockdown efficiency of FBXL8 in MCF7 and MDA-MB231 cells (Figure 3B), we noted a reduction in cell viability by $52.5 \%$ within $48 \mathrm{~h}$ (an average taken from MTT and CTB assays) (Figure 3C, D), which was significantly different $(p<0.001)$ from that of control siRNA-treated cells. 
medRxiv preprint doi: https://doi.org/10.1101/2020.06.09.20127068; this version posted June 11, 2020. The copyright holder for this preprint (which was not certified by peer review) is the author/funder, who has granted medRxiv a license to display the preprint in perpetuity.

It is made available under a CC-BY-NC-ND 4.0 International license .

of both MCF7 and MDA-MB231 cells (Figure 3E, F, $p<0.001$ ). This reduction in cell proliferation is supported by significant increases in early apoptosis of $20 \%$ and $24 \%$ in FBXL8-knocked down MCF7 and MDA-MB231 cells, respectively (Figure 3G). Representative histograms of apoptosis assay are shown in Supplementary Figure S4 $(p<0.001)$. Further investigation of Caspase activity showed that both Caspases-9 and -3 were activated in FBXL8 knocked down cells (Figure $3 \mathbf{H}$ ), indicating that the presence/ increase in FBXL8 prevents intrinsic apoptosis and confers survival advantage to $\mathrm{BRCA}$, hence favoring cancer progression.

\section{Knockdown of FBXL8 inhibited BRCA cell migration and invasion.}

To further investigate the impact of FBXL8 as a driver of BRCA metastasis, we examined the effects of FBXL8-knockdown on cell migration and invasion. When monitored over $30 \mathrm{~h}$, the highly invasive MDA-MB231 cells showed $40 \%$ slowdown in cell migration compared to $14 \%$ with the less invasive MCF7 (both compared to control siRNA-treated cells, $p<0.001$ ) (Figure 4A, B, C, D). Consistently, cell invasion was suppressed by 4-8 fold in MDA-MB231 and MCF7 cells $(p<0.001)$ (Figure 4E, F). Importantly, direct analysis of cell growth showed that the doubling time for MCF7 and MDA-MB231 cells was $26 \mathrm{~h}$ and $23 \mathrm{~h}$, respectively (Fig. 3D). The 4-8 fold reduction in invasion observed at $24 \mathrm{~h}$ therefore cannot be solely attributable to the inhibition of cell growth or a difference in cell doubling time. These results again support that FBXL8 is a significant contributor to BRCA cell growth and metastasis.

\section{Knockdown of FBXL8 suppressed pro-inflammatory cytokines/chemokines in BRCA.}

There is increasing evidence that the SCF E3 ubiquitin machinery favors cancer formation by controlling immunomodulators such as cytokines which are abundant in 
medRxiv preprint doi: https://doi.org/10.1101/2020.06.09.20127068; this version posted June 11, 2020. The copyright holder for this preprint (which was not certified by peer review) is the author/funder, who has granted medRxiv a license to display the preprint in perpetuity.

It is made available under a CC-BY-NC-ND 4.0 International license .

the tumor microenvironment $(8,9,23)$. It was therefore pertinent for us to examine whether and how FBXL8 might regulate the cytokines. A cytokine array analysis of FBXL8-knocked down BRCA cells showed that the loss of FBXL8 caused a downregulation of the pro-tumorigenic factors, including MCP-1, I-TAC, TECK, CTACK, MIF, GM-CSF, NT-3, FGF-6, Angiogenin, ICAM-1, DtK and EGFR (Fig. 5A). Interestingly, we observed that Angiogenin, GM-CSF, ICAM-1 and EGFR were dramatically over-expressed (for example, up to 20-fold increase for EGFR) in the highly invasive MDA-MB231 cells compared to the less invasive MCF7 cells. Previous findings have also shown that these factors support the survival of breast cancer cells and promote angiogenesis, further triggering cancer invasion and metastatic spread (24-27). Additionally, NT-3, which was concomitantly decreased by knockdown of FBXL8, has been reported to modulate the tumor microenvironment to promote breastto-brain metastasis (28). Suffice to say, knockdown of the pro-tumorigenic FBXL8 caused the loss of another pro-tumorigenic factor, NT-3, which plausibly further restrains $B R C A$ metastasis. It would be interesting, in future, to examine the potential functional partnership between FBXL8 and NT-3, in their co-regulation of BRCA progression.

Quantification by ELISA further affirmed that depletion of FBXL8 significantly reduced the production of several inflammatory cytokines and chemokines e.g. GMCSF, MCP-1, CTACK, EGFR, ICAM-1, I-TAC, MIF and TECK (Figure 5B, blue bars). Such cytokines/chemokines are reported to promote cancer, and are associated with cancer survival, growth and/or metastasis in $\operatorname{BRCA}(25,29-36)$. The association of these cytokines to FBXL8 activity suggests that FBXL8 promotes BRCA survival by modulating the cytokine/chemokine-rich pro-tumorigenic microenvironment.

On the other hand, Osteoprotegerin (OPG, overexpressed in BRCA metastasis) is up-regulated in MCF7 and down-regulated in MDA-MB231 during FBXL8 
medRxiv preprint doi: https://doi.org/10.1101/2020.06.09.20127068; this version posted June 11, 2020. The copyright holder for this preprint (which was not certified by peer review) is the author/funder, who has granted medRxiv a license to display the preprint in perpetuity.

It is made available under a CC-BY-NC-ND 4.0 International license .

knockdown. Although we found opposite trends of OPG in the two BRCA cell types, higher levels of OPG have been associated with an increased risk of ER-negative BRCA (37). Similarly, knockdown of FBXL8 increased the expression of protumorigenic TNFR1. Inhibition of TNFR1 expression was reported to increase apoptosis, and inhibit cell proliferation and invasion in triple-negative and ER positive BRCA cells (38). IL-6R was negatively regulated by FBXL8 expression, although IL-6 appeared unaffected by FBXL8 knockdown. Such data highlight the complexity of FBXL8-associated immune network. It is plausible that the BRCA tissues contained heterogeneous tumor cell types. Therefore, our findings suggest the propensity for developing variant forms of FBXL8-based combinatorial treatments possibly with FBXL8-mediated cytokines or FBXL8-binding partners, for specific and targeted chemotherapy against different heterogeneous forms of BRCA. This prompted us to further search for and characterize FBXL8-binding partners.

\section{Cancer-suppressors, CCND2 and IRF5, are FBXL8-binding partners in BRCA}

FBXL8 is a leucine-rich repeat protein member of the E3 SCF multimeric complex. Our in silico modeling prediction revealed FBXL8-binding partners including CUL1, SKP1, CUL2 and CUL7 (Supplementary Figure S5). These results support the involvement of E3 ligase in promoting BRCA. In addition, several non-SCF E3 ligaseassociated components were proposed, including cell-cycle associated proteins, cancer-promoting transcription factors and DNA repair/replication factors. Notably, two cancer suppressors, CCND2 (Cyclin D2) and IRF5 (Interferon Regulatory Factor 5), emerged prominently as potential interaction partners of FBXL8. Knockdown of CCND2 has been reported to increase the growth rate and migration ability of cancer cells (39). On the other hand, IRF5 overexpression is capable of reverting MDA-MB231 to normal acini-like structures (20). Notably, our IHC staining of breast carcinoma 
medRxiv preprint doi: https://doi.org/10.1101/2020.06.09.20127068; this version posted June 11, 2020. The copyright holder for this preprint (which was not certified by peer review) is the author/funder, who has granted medRxiv a license to display the preprint in perpetuity.

It is made available under a CC-BY-NC-ND 4.0 International license .

tissues demonstrated a reciprocal profile of FBXL8 versus CCND2 and IRF5 with cancer advancement over stages I - III. Clearly, the FBXL8 level increased while CCND2 and IRF5 levels decreased (Figure 6A, B, C), thus: (i) corroborating the significant role of CCND2 and IRF5 as BRCA-suppressors and (ii) highlighting the potential role of FBXL8 in specific degradation of CCND2 and IRF5 proteins as cancer progresses. The mRNA levels of CCND2 and IRF5 were further examined by both NGS-based RNA-Seq and TCGA database analyses. Figure 6D, E, F, G showed that the IRF5 mRNA was significantly upregulated in breast tumor tissues (Fig. 6G), although its protein level was reduced in BRCA tissues. This suggests potential posttranslational modifications which led to the loss of IRF5 proteins in BRCA.

Gilt by association, we next investigated whether anti-cancer CCND2 and IRF5 are binding partners of FBXL8, with a view to providing explanations on how their interactions might impact BRCA progression. Co-immunoprecipitation (Co-IP) showed that FBXL8 pulled down both CCND2 and IRF5 in MCF-7 and MDA-MB231 cells (Figure $6 \mathrm{H}$ ), indicating that CCND2 and IRF5 are conserved specific substrates of FBXL8 E3 ligase. IP with control $\operatorname{lgG}_{2 b}$ demonstrated the specificity of the assay. Importantly, we showed that knockdown of FBXL8 caused the accumulation of CCND2 and IRF5 (but not tubulin) proteins in both BRCA cell lines, suggesting that FBXL8 selectively regulates the protein degradation of CCND2 and IRF5 (Figure 6I), thus explaining why FBXL8 rises while CCND2 and IRF5 declines as BRCA progresses. Given the critical role of CCND2 and IRF5 in cell cycle regulation as growth-inhibitors $(18,20)$, our data here account the functional significance of FBXL8 as a tumorpromoter, whose knockdown spared the tumor suppressors, CCND2 and IRF5 from degradation, thus allowing them to accumulate and suppress BRCA progression. 
medRxiv preprint doi: https://doi.org/10.1101/2020.06.09.20127068; this version posted June 11, 2020. The copyright holder for this preprint (which was not certified by peer review) is the author/funder, who has granted medRxiv a license to display the preprint in perpetuity.

It is made available under a CC-BY-NC-ND 4.0 International license .

\section{Discussion}

Due to the lack of early symptoms and a dearth of markers for dynamic progression of BRCA, breast cancer malignancy is often detected too late. BRCA appears to be associated with inflammation and immune-overactivation conditions, which perpetuates cancer recurrence and lowers patient survival rate (13). Concordant with our earlier findings that showed the involvement of SCF E3 in inflammation and tumorigenesis (11), treatment with non-steroidal anti-inflammatory drugs has been shown to reduce BRCA metastasis and recurrence of the disease $(40,41)$. Other clinical efforts to arrest BRCA have used Bortezomib (Velcade or PS-341), the first proteasome inhibitor to be approved by FDA. Unfortunately, Bortezomib was found to be cytotoxic due to its inhibition of protein degradation on a global scale (42). Therefore, we reasoned that the ideal approach is to target a specific protein degradation enzyme like an E3 ligase, where different F-box factor family members are selectively activated in a disease-specific manner (43). This approach will improve the specificity of antiBRCA targeting. Here, by retrospective studies with BRCA patient tissues $(n=134$ from Taiwan BioBank and $n=1215$ from TCGA database), we report that FBXL8, a novel Fbox E3 ligase family member, is significantly correlated with BRCA disease progression. For the first time, we revealed the pathobiological functions of FBXL8 and elucidated its functional significance ex vivo. We found that FBXL8 blocks apoptosis of BRCA cells and modulates cytokine profiles to promote a pro-inflammatory condition. Furthermore, we showed that knockdown of FBXL8 induced intrinsic apoptosis of the BRCA cells, suggesting that FBXL8 promotes BRCA advancement, as supported by the involvement of other F-box proteins in regulating the EMT process in cancers (14). Consistently, we demonstrated that the loss of FBXL8 decreased cell migration and invasion, affirming that FBXL8 is a key promoter of BRCA progression. This is strongly corroborated by the increase in FBXL8 level as the disease advanced in BRCA patients 
medRxiv preprint doi: https://doi.org/10.1101/2020.06.09.20127068; this version posted June 11, 2020. The copyright holder for this preprint (which was not certified by peer review) is the author/funder, who has granted medRxiv a license to display the preprint in perpetuity.

It is made available under a CC-BY-NC-ND 4.0 International license .

(Figure $\left.2 ;{ }^{* *}, p<0.01 ;{ }^{* * *}, p<0.001\right)$. Congruent to these findings, knockdown of FBXL8 significantly down-regulated cancer-promoting cytokines and chemokines. Therefore, repression of FBXL8 is a potential anticancer strategy to activate apoptosis, to inhibit metastasis, and to modulate pro-tumorigenic cytokines in BRCA (Figure 7A).

Further insights on the translational impact of FBXL8 was accrued from in silico modeling prediction, which revealed various potential interaction partners of FBXL8, for example: Cyclin family members like cancer suppressor $\underline{\text { CCND2 }}$ (18), $\underline{\text { IRF5}}$ (Interferon Regulatory Factor 5), and DNA repair /replication associated proteins (Nibrin and SMAD4) (Figure S5). Thus, FBXL8 appears rather promiscuous, associating with multiple binding partners, to plausibly promote cancer formation and progression through the turnover of: (i) cell-cycle associated proteins, (ii) cancersuppressors and (iii) proteins responsible for DNA repair/replication. We further validated two of the in silico predicted binding partners, CCND2 and IRF5 (tumorsuppressors), and empirically demonstrated their functional roles which might countermeasure FBXL8, in cancer cells. Notably, the specificity of ubiquitination is mainly controlled at the level of E3 ligase (44), and it is possible that CCND2 and IRF5 are the specific substrates targeted for degradation by FBXL8, an E3 ligase. The molecular axes of interactions of FBXL8-CCND2, FBXL8-IRF5 and/or FBXL8-CCND2$\underline{\text { IRF5 }}$ prompted us to speculate that their partnership(s) could fine-tune and maintain cellular homeostasis (Figure 7B). Should the balance of this partnership tip over in favor of FBXL8, the tumorigenic potential will rise. Since IRF-5 has been reported to stimulate inflammatory genes $(20,45)$, the involvement of IRF5 indicates how FBXL8 might indirectly influence the cytokine profiles, hence promoting a pro-inflammatory cytokine-rich cancer microenvironment, as our results alluded to (Figure 5). Additionally, since IRF5 itself can also acts as a pro-tumorigenic factor (46), it is plausible that besides E3, different E2s in the UPS may also respond to the 
medRxiv preprint doi: https://doi.org/10.1101/2020.06.09.20127068; this version posted June 11, 2020. The copyright holder for this preprint (which was not certified by peer review) is the author/funder, who has granted medRxiv a license to display the preprint in perpetuity.

It is made available under a CC-BY-NC-ND 4.0 International license .

pathophysiological conditions to modulate the FBXL8-IRF5 axis, which should enhance the tumorigenic and metastatic potential.

Since FBXL8-knockdown raised the levels of CCND2 and IRF5, which resulted in cancer suppression, it is conceivable that as a tumor-promoter, FBXL8 acts as a dominant member of a tripartite liaison, in which FBXL8 controls the two tumor suppressors, CCND2 and IRF5 (Figure 6). Of significance is that FBXL8 is a specific protein degradation enzyme which selectively targets cancer suppressors like CCND2 and IRF5. Unlike Bortezomib which is a general protein degradation enzyme, we propose that FBXL8-blockers can be developed to specifically unleash CCDN2 and IRF5, in BRCA treatment. Furthermore, antibodies against the pro-inflammatory cytokines, and/or binding partners identified in this study may be employed clinically in combination with FBXL8-blocker to treat heterogeneous variants of BRCA.

\section{Acknowledgements}

The authors thank Dr. I-Hsuan Lin and Dr. Tsung-Han Hsieh, TMU Cancer Translational Core Facility for the NGS-based RNA-seq technology support. This work was jointly supported by the Ministry of Science and Technology, Taiwan (MOST1052320-B-038-007-MY2, MOST107-2314-B-038-066); Taipei Medical University (TMU104-AE1-B10, 105TMU-TMUH-06); the Ministry of Education (R-154-000-A76114) and the National University of Singapore Graduate School of Integrative Sciences and Engineering (NGS, C-154-000-017-091), Singapore.

\section{Author Contributions}

S.C.C. designed, conducted the experiments and wrote the paper; W.H. and C.Y.S. verified the analytical methods; C.S.H. provided the human primary samples and designed the experiments; J.L.D. designed the experiments and wrote the paper. 
medRxiv preprint doi: https://doi.org/10.1101/2020.06.09.20127068; this version posted June 11, 2020. The copyright holder for this preprint (which was not certified by peer review) is the author/funder, who has granted medRxiv a license to display the preprint in perpetuity.

It is made available under a CC-BY-NC-ND 4.0 International license .

\section{Competing interests}

The authors declare no conflict of interest.

\section{Materials and Methods}

\section{Tissue samples}

67 pairs of tissue samples (tumor and normal tissues; $n=134$ ) from BRCA patients were acquired from the BioBank, Taipei Medical University, Taiwan, after clinical diagnosis was confirmed by biopsy and histological evaluation. All patient samples were collected with informed consent. The study was approved by the TMU-JIRB (Taipei Medical University-Joint Institutional Review Board; IRB: N201803107). Adjacent noncancerous breast tissues were obtained at least $2 \mathrm{~cm}$ away from the tumor node, to serve as paired normal tissue control. Ex vivo experiments included (i) NGS-based RNA-seq analysis, where five-pairs of the primary tissues $(n=10)$ were obtained from: one stage I, three stage II and one stage III patient samples (the corresponding clinicopathological information are shown in Figure 1A); (ii) qRT-PCR analysis of 32 paired tissues ( $n=64$ ), including fifteen stage I, nine stage II and eight stage III patient samples (the corresponding clinicopathological information are shown in Supplementary Figure S1); and (iii) immunofluorescence staining, where 30 pairs of the tissues $(n=60)$ were used, including: nine stage I, eleven stage II and ten stage III patient samples (the corresponding clinicopathological information are shown in Supplementary Figure S2). H\&E sections were obtained from the BioBank, Taipei Medical University, Taiwan. For immunofluorescence staining, paraffin-embedded tissues were sectioned at $5 \mu \mathrm{m}$ thickness, dehydrated and blocked in Ultravision Protein Block (Thermo Scientific TA060PBQ) for $10 \mathrm{~min}$ at room temperature. Then, the sections were incubated with primary and secondary antibodies overnight and $1 \mathrm{~h}$, respectively. The stained tissue sections were observed under a microscope (Olympus, 
medRxiv preprint doi: https://doi.org/10.1101/2020.06.09.20127068; this version posted June 11, 2020. The copyright holder for this preprint (which was not certified by peer review) is the author/funder, who has granted medRxiv a license to display the preprint in perpetuity.

It is made available under a CC-BY-NC-ND 4.0 International license .

Tokyo, Japan) and images were acquired using software (EOS Utility, Canon).

\section{Cell lines and reagents}

Human BRCA cell lines (MCF7, MDA-MB231) and an FBXL8-negative control breast cell line (MCF10A) were obtained from American Type Culture Collection (ATCC). MCF7 and MDA-MB231 were cultured in complete DMEM medium (Gibco). MCF10A was cultured in complete DMEM/F12 medium (Gibco). All the complete media were supplemented with $10 \%$ FBS (Thermo Scientific) and $100 \mathrm{U} / \mathrm{ml}$ penicillin and 100 $\mu \mathrm{g} / \mathrm{ml}$ streptomycin (Invitrogen). Antibodies used in $\mathrm{IHC}$, immune blotting and immunoprecipitation analysis were anti-FBXL8 antibody (sc-390582, Santa Cruz Biotechnology, Dallas, TX, USA), anti-ubiquitin antibody (ab7780, Abcam, Cambridge, UK), anti-CCND2 antibody (ab226972, Abcam, Cambridge, UK), anti-IRF5 antibody (ab2932, Abcam, Cambridge, UK), normal mouse lgG2b (sc-3879, Santa Cruz Biotechnology, Dallas, TX, USA) and anti-Tubulin antibody (ab176560, Abcam, Cambridge, UK).

\section{Next-generation sequencing (NGS)-based RNA-seq analysis}

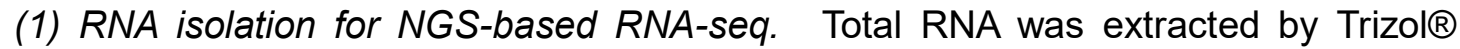
Reagent (Invitrogen, USA) according to the instruction manual. Purified RNA was quantified at $\mathrm{OD}_{260 n m}$ by using Qubit (Life Technologies, Qubit ${ }^{\circledR} 2.0$ Fluorometer, USA) and analysed using a bioanalyzer (Agilent, Bioanalyzer 2100 system, USA) with RNA 6000 labchip kit (Agilent Technologies, USA).

(2) Library preparation \& sequencing for NGS-based RNA-Seq application. All procedures were carried out according to the manufacturer's protocol from Illumina. Library construction of all samples was performed using Agilent's SureSelect Strand Specific RNA Library Preparation Kit (100SE, Single-End) bp sequencing on Solexa 
medRxiv preprint doi: https://doi.org/10.1101/2020.06.09.20127068; this version posted June 11, 2020. The copyright holder for this preprint (which was not certified by peer review) is the author/funder, who has granted medRxiv a license to display the preprint in perpetuity.

It is made available under a CC-BY-NC-ND 4.0 International license .

platform. The sequences were determined using sequencing-by-synthesis technology via the TruSeq SBS Kit. Raw sequences were obtained from the Illumina Pipeline software bcl2fastq v2.0, which was expected to generate 5M (million reads) per sample. (3) RNA sequence analysis. Quality control of raw sequence data was performed with FastQC. Adapter and quality trimming was performed using cutadapt (phred cutoff: 20; minimum length: 25) (47). Reads were mapped to the human reference genome using STAR aligner indexed with GRCh37 assembly and GENCODE Release 26 v26lift37 annotation. Gene expression was quantified using RSEM. The expected counts were used as input for the differential gene expression analysis between tumor and adjacent-normal BRCA samples using edgeR in the $R$ environment. A false discovery rate (FDR) $<0.05$ was used as a threshold to define genes that showed statistically significant differential expression. A log2 fold change (logFC) less than 0 indicates under-expression in the tumor samples, whereas logFC greater than 0 represents over-expression in the tumor samples.

\section{TCGA database analysis}

TCGA breast cancer transcript dataset was downloaded from $\mathrm{R}$ package, TCGAbiolinks (48). In total, 1215 primary tissues were analyzed, including 1102 carcinoma tissues and 113 normal tissues. All of the raw counts were used as input for the differential gene expression analysis between tumor and normal breast samples, using DESeq2. The $P$ adjust value $<0.05$ was used as threshold to define genes that showed statistically significant differential expression.

\section{Quantitative real-time PCR}

$24 \mathrm{~h}$ after treatment of cell lines, total RNA was extracted with TRIzol reagent (Invitrogen) and the RNA was reverse transcribed using random hexamers and 
medRxiv preprint doi: https://doi.org/10.1101/2020.06.09.20127068; this version posted June 11, 2020. The copyright holder for this preprint (which was not certified by peer review) is the author/funder, who has granted medRxiv a license to display the preprint in perpetuity.

It is made available under a CC-BY-NC-ND 4.0 International license .

HiSenScript ${ }^{\mathrm{TM}} \mathrm{RH}(-)$ RT-PCR PreMix Kit (iNtRON Biotechnology, Seongnam, South Korea), according to the manufacturer's instructions. The synthesized cDNA was used for real-time PCR analysis using SYBR Green (Life Technologies) on a QuantStudio 3 Real-Time PCR System (Applied Biosystems, Foster City, CA, USA). The primers were human FBXL8 (83 bp product): sense, 5'-AATCAGTTGCGAATGTGAGC-3'; antisense, 5'-CCAGCCGTAGGTTGTGAATG-3'; human SAG (109 bp product): sense, 5'CAGGCTCCAAGTCGGGAGGCG-3', antisense, 5'TGGACCCTGCAGATGGCACAGG-3'; human GAPDH (131 bp product): sense, 5'GTCTCCTCTGACTTCAACAGCG-3', antisense, 5'ACCACCCTGTTGCTGTAGCCAA-3'. All expression values were normalized based on GAPDH as an endogenous control.

\section{FBXL8 knockdown in BRCA cells}

FBXL8 siRNA (siGENOME Human FBXL8-SMARTpool, M-017504-00-0005) was purchased from Dharmacon (Lafayette, CO, USA). Control (scrambled) siRNA were purchased from Invitrogen. siGENOME Human FBXL8-SMARTpool contains a mixture of 4 siRNAs provided as a single reagent; providing advantages in both potency and specificity, which was anticipated to achieve silencing effects $>75 \%$. siRNA transfection into MCF7 or MDA-MB231 cells (at $5 \times 10^{5}$ cells per well of a 6 -well plate) was conducted using $7.5 \mu$ TransIT-X2 Transfection Reagent (Mirus) with $25 \mathrm{nM}$ of siRNAs per well.

\section{Cell viability assay}

Both MTT \{3-(4,5-dimethylathiazol-2-yl)-2,5-diphenyl tetrazolium bromide\} and CTB (CellTiter Blue) obtained from Life Technologies (Carlsbad, CA, USA) and Promega (Madison, WA, USA), respectively, were used to determine the cell viability, according 
medRxiv preprint doi: https://doi.org/10.1101/2020.06.09.20127068; this version posted June 11, 2020. The copyright holder for this preprint (which was not certified by peer review) is the author/funder, who has granted medRxiv a license to display the preprint in perpetuity.

It is made available under a CC-BY-NC-ND 4.0 International license .

to the manufacturer's instructions. To assess the cell viability the functional mitochondrial activity was measured by incubating the cells with either $10 \mu \mathrm{l}$ MTT reagent in $100 \mu \mathrm{l}$ culture medium at $37^{\circ} \mathrm{C}$ for $4 \mathrm{~h}$, or $10 \mu \mathrm{CTB}$ reagent at $37^{\circ} \mathrm{C}$ for 4 h. The metabolic activity of viable cells was measured at $570 \mathrm{~nm}$ using a Synergy $\mathrm{H} 4$ microplate reader (BioTek, Winooski, VT, USA) at time points indicated. Samples from each time point were normalized with corresponding PBS controls.

\section{Cell proliferation assay}

After cells are transfected with FBXL8-specific siRNA or control scrambled siRNA for $16 \mathrm{~h}$, both Alamar blue and Trypan Blue dye exclusion were used to measure the cell proliferation. The cell growth was measured by Alamar blue. The metabolic activity of the cells was determined at $570 \mathrm{~nm}$ using a Synergy H4 microplate reader (BioTek, Winooski, VT, USA) at time points indicated. For Trypan Blue dye exclusion, to assess total cell number, cells were scraped and resuspended in equal volumes of culture medium and trypan blue dye ( $0.4 \%$ solution; Gibco, Waltham, MA, USA) and counted using an improved Neubauer hemocytometer.

\section{Cellular apoptosis assay}

MCF7 and MDA-MB231 cells were transfected with FBXL8-specific siRNA or control scrambled siRNA for $24 \mathrm{~h}$, followed by determination of apoptosis. Early apoptosis was measured using annexin V (BioLegend, San Diego, CA, USA) in conjunction with 7AAD (BioLegend), according to manufacturer's instructions. Annexin $V$ identifies surface-exposed phosphatidylserine, and 7-AAD is retained in late apoptotic cells. Early apoptosis (Annexin $\mathrm{V}^{+} / 7-\mathrm{AAD}^{-}$) was then analyzed using FACScan flow cytometer (FACSVerse, BD Biosciences, Franklin Lakes, NJ, USA) for a minimum of 10,000 events. 
medRxiv preprint doi: https://doi.org/10.1101/2020.06.09.20127068; this version posted June 11, 2020. The copyright holder for this preprint

\section{Caspases -9 and -3 assays}

$24 \mathrm{~h}$ after the transfection of FBXL8-specific siRNA or control scrambled siRNA, apoptosis of MCF7 and MDA-MB231 cells were examined by determining the caspasespecific cleavages of activated caspases- 9 and -3 (Abcam). The p-nitroanilide ( $p-N A)$ light emission was measured at $405 \mathrm{~nm}$ using a Synergy H4 microplate reader (BioTek).

\section{Cell migration and invasion assays}

$24 \mathrm{~h}$ after treatment of the MCF7 and MDA-MB231 cells with FBXL8-siRNA or controls, cell migration assay was performed. The cells were rinsed with PBS, harvested using $0.05 \%$ Trypsin-EDTA (Invitrogen) and plated into a 2-well Culture-Insert (ibidi, Martinsried, Germany) according to the manufacturer's instructions. The CultureInserts were removed after $16 \mathrm{~h}$, and cell migration was monitored over indicate timescale. For cell invasion assay, biocoat matrigel invasion chambers with 8- $\mu \mathrm{m}$ pores in 24-well plates (Corning, Discovery Labware, Inc., Bedford, MA, USA) were used. $24 \mathrm{~h}$ after siRNA transfection, the cells were plated onto the chambers. The cells were detached with $0.05 \%$ Trypsin-EDTA, resuspended in conditioned medium (10 \% FBS) and added to the upper compartment of the chambers, according to the manufacturer's instructions. After $24 \mathrm{~h}$ of incubation at $37^{\circ} \mathrm{C}$, the cells on the upper surface were completely removed by wiping with a cotton swab, and then the filter was fixed with $100 \%$ methanol and stained with crystal violet solution $(0.5 \%(\mathrm{w} / \mathrm{v})$ crystal violet in $25 \%(\mathrm{v} / \mathrm{v}$, methanol). Cells that had migrated from the upper to the lower side of the filter were imaged and counted with a light microscope (5 fields/filter).

\section{Cytokine arrays}

The secretion of cytokines from BRCA cells effected by FBXL8-knockdown was 
medRxiv preprint doi: https://doi.org/10.1101/2020.06.09.20127068; this version posted June 11, 2020. The copyright holder for this preprint (which was not certified by peer review) is the author/funder, who has granted medRxiv a license to display the preprint in perpetuity.

It is made available under a CC-BY-NC-ND 4.0 International license .

analyzed using human cytokine antibody array (human cytokine antibody array C6 and C7, AAH-CYT-1000) purchased from RayBiotech (Peachtree Corners, GA, USA). Cells were cultured in complete medium with transfection of FBXL8-specific siRNA or control scrambled siRNA for $48 \mathrm{~h}$. Culture supernatants were collected for cytokine antibody array analysis. Cytokine signal intensities were quantified by Scion Image software (Frederick, MD, USA). The fold-change of cytokines secreted from cells was calculated by normalization of FBXL8-specific siRNA-treated samples to control scrambled siRNA-treated samples.

\section{ELISA quantification of cytokines}

To determine the effects of FBXL8 on cytokine release, both MCF7 and MDA-MB231 were transiently transfected with FBXL8-specific siRNA or control siRNA for $48 \mathrm{~h}$. The levels of MCP-1, EGFR, I-TAC, TECK, CTACK, MIF, GM-CSF and ICAM-1 (based on the cytokine array results), secreted by the cells, were quantified in supernatants derived from 48-h cultures, by using the respective ELISA (R\&D systems, Minneapolis, MN, USA), according to manufacturer's instructions.

\section{Co-IP and immunodetection}

For Co-IP study with MCF7 or MDA-MB231 total cell lysates, the cells were lysed in CHAPS lysis buffer containing $20 \mathrm{mM}$ Tris- $\mathrm{HCl}, \mathrm{pH} 7.5,5 \mathrm{mM} \mathrm{MgCl} 2,137 \mathrm{mM} \mathrm{KCl}, 1$ mM EDTA, 1 mM EGTA, 1\% CHAPS and 1 protease inhibitors (complete EDTA-free cocktail, Roche). Then, the cell lysate was precleared by incubating with protein $G$ Sepharose (GE Healthcare, Little Chalfont, UK) at $4{ }^{\circ} \mathrm{C}$ for $2 \mathrm{~h}$. The supernatant was incubated overnight at $4{ }^{\circ} \mathrm{C}$ with FBXL8 or control $\operatorname{lgG}_{2 b}$ antibody, followed by a 3-h incubation with protein G Sepharose. The washed immunoprecipitates, resuspended in Laemmli buffer, was boiled at $95^{\circ} \mathrm{C}$ for 5 min before immunodetection of FBXL8, 
medRxiv preprint doi: https://doi.org/10.1101/2020.06.09.20127068; this version posted June 11, 2020. The copyright holder for this preprint (which was not certified by peer review) is the author/funder, who has granted medRxiv a license to display the preprint in perpetuity.

It is made available under a CC-BY-NC-ND 4.0 International license .

CCND2 or IRF5.

\section{Statistical analysis}

Data were expressed as means \pm S.D. from three independent experiments, with three replicates per sample/condition tested. Differences between averages were analyzed by two-tailed Student's t-test. Significance was set at $p$-value of $<0.01{ }^{* *}, p<0.01$; ${ }^{* * *}$, $p<0.001)$. The acquired data from FACS were analyzed with BD FACSuite ${ }^{\mathrm{TM}}$ software (BD Biosciences, CA, USA). The relative migration rate, indicated as \% gap closure, was calculated using Image $\mathrm{J}$ analysis software. All target signals from IHC were quantified by HistoQuest software (TissueGnostics, Vienna, Austria).

\section{References}

1. Coughlin SS, Ekwueme DU. Breast cancer as a global health concern. Cancer Epidemiology. 2009;33(5):315-8.

2. Jemal A, Siegel R, Xu J, Ward E. Cancer Statistics, 2010. CA: A Cancer Journal for Clinicians. 2010;60(5):277-300.

3. Orlowski RZ, Dees EC. The role of the ubiquitination-proteasome pathway in breast cancer: applying drugs that affect the ubiquitin-proteasome pathway to the therapy of breast cancer. Breast cancer research : BCR. 2003;5(1):1-7.

4. Randle SJ, Laman H. F-box protein interactions with the hallmark pathways in cancer. Seminars in Cancer Biology. 2016;36:3-17.

5. Soucy TA, Smith PG, Rolfe M. Targeting NEDD8-Activated Cullin-RING Ligases for the Treatment of Cancer. Clinical Cancer Research. 2009;15(12):3912-6.

6. Soucy TA, Smith PG, Milhollen MA, Berger AJ, Gavin JM, Adhikari S, et al. An inhibitor of NEDD8-activating enzyme as a new approach to treat cancer. Nature. 2009;458(7239):732-6.

7. Chen X, Cui D, Bi Y, Shu J, Xiong X, Zhao Y. AKT inhibitor MK-2206 sensitizes breast cancer cells to MLN4924, a first-in-class NEDD8-activating enzyme (NAE) inhibitor. Cell Cycle. 2018;17(16):2069-79.

8. Chang SC, Ding JL. Ubiquitination and SUMOylation in the chronic inflammatory tumor microenvironment. Biochimica et Biophysica Acta (BBA) - Reviews on Cancer. 2018.

9. Mathewson N, Toubai T, Kapeles S, Sun Y, Oravecz-Wilson K, Tamaki H, et al. Neddylation plays an important role in the regulation of murine and human dendritic cell function. Blood. 
medRxiv preprint doi: https://doi.org/10.1101/2020.06.09.20127068; this version posted June 11, 2020. The copyright holder for this preprint (which was not certified by peer review) is the author/funder, who has granted medRxiv a license to display the preprint in perpetuity.

It is made available under a CC-BY-NC-ND 4.0 International license.

2013;122(12):2062-73.

10. Nakayama KI, Nakayama K. Ubiquitin ligases: cell-cycle control and cancer. Nature Reviews Cancer. 2006;6(5):369-81.

11. Chang SC, Ding JL. Ubiquitination by SAG regulates macrophage survival/death and immune response during infection. Cell Death Differ. 2014;21(9):1388-98.

12. Chang SC, Choo WQW, Toh HC, Ding JL. SAG-UPS attenuates proapoptotic SARM and Noxa to confer survival advantage to early hepatocellular carcinoma. Cell Death Discovery. 2015;1:15032.

13. Pierce BL, Ballard-Barbash R, Bernstein L, Baumgartner RN, Neuhouser ML, Wener MH, et al. Elevated biomarkers of inflammation are associated with reduced survival among breast cancer patients. Journal of clinical oncology : official journal of the American Society of Clinical Oncology. 2009;27(21):3437-44.

14. Song Y, Lin M, Liu Y, Wang Z-W, Zhu X. Emerging role of F-box proteins in the regulation of epithelial-mesenchymal transition and stem cells in human cancers. Stem Cell Research \& Therapy. 2019;10:NA.

15. Wang Z, Liu P, Inuzuka H, Wei W. Roles of F-box proteins in cancer. Nature Reviews Cancer. 2014;14(4):233-47.

16. Kipreos ET, Pagano M. The F-box protein family. Genome Biology. 2000;1(5):reviews3002.1.

17. Skaar JR, Pagan JK, Pagano M. Mechanisms and function of substrate recruitment by F-box proteins. Nature reviews Molecular cell biology. 2013;14(6):369-81.

18. Sakuma M, Akahira J-i, Ito K, Niikura H, Moriya T, Okamura K, et al. Promoter methylation status of the Cyclin D2 gene is associated with poor prognosis in human epithelial ovarian cancer. Cancer Science. 2007;98(3):380-6.

19. Hu G, Mancl ME, Barnes BJ. Signaling through IFN Regulatory Factor-5 Sensitizes p53-Deficient Tumors to DNA Damage-Induced Apoptosis and Cell Death. Cancer Research. 2005;65(16):7403-12.

20. Bi X, Hameed M, Mirani N, Pimenta EM, Anari J, Barnes BJ. Loss of interferon regulatory factor 5 (IRF5) expression in human ductal carcinoma correlates with disease stage and contributes to metastasis. Breast cancer research : BCR. 2011;13(6):R111-R.

21. Duan H, Wang Y, Aviram M, Swaroop M, Loo JA, Bian J, et al. SAG, a Novel Zinc RING Finger Protein That Protects Cells from Apoptosis Induced by Redox Agents. Molecular and Cellular Biology. 1999;19(4):3145-55.

22. Jia L, Yang J, Hao X, Zheng M, He H, Xiong X, et al. Validation of SAG/RBX2/ROC2 E3 Ubiquitin Ligase as an Anticancer and Radiosensitizing Target. Clinical Cancer Research. 2010;16(3):814-24.

23. Chang SC, Ding JL. SAG-UPS regulates malignant transformation[mdash]from chronic inflammation to pro-tumorigenesis to liver cancer. Cell Death Dis. 2015;6:e1941.

24. Dutta S, Bandyopadhyay C, Bottero V, Veettil MV, Wilson L, Pins MR, et al. Angiogenin interacts with the plasminogen activation system at the cell surface of breast cancer cells to regulate plasmin formation and cell migration. Molecular oncology. 2014;8(3):483-507. 
medRxiv preprint doi: https://doi.org/10.1101/2020.06.09.20127068; this version posted June 11, 2020. The copyright holder for this preprint (which was not certified by peer review) is the author/funder, who has granted medRxiv a license to display the preprint in perpetuity.

It is made available under a CC-BY-NC-ND 4.0 International license.

25. Reggiani F, Bertolini F. GM-CSF promotes a supportive adipose and lung microenvironment in metastatic breast cancer. Oncoscience. 2017;4(9-10):126-7.

26. Köstler WJ, Tomek S, Brodowicz T, Budinsky AC, Flamm M, Hejna M, et al. Soluble ICAM-1 in breast cancer: clinical significance and biological implications. Cancer Immunology, Immunotherapy. 2001;50(9):483-90.

27. Dickler MN, Cobleigh MA, Miller KD, Klein PM, Winer EP. Efficacy and safety of erlotinib in patients with locally advanced or metastatic breast cancer. Breast Cancer Research and Treatment. 2009;115(1):115-21.

28. Louie E, Chen XF, Coomes A, Ji K, Tsirka S, Chen EI. Neurotrophin-3 modulates breast cancer cells and the microenvironment to promote the growth of breast cancer brain metastasis. Oncogene. 2013;32(35):4064-77.

29. Dutta P, Sarkissyan M, Paico K, Wu Y, Vadgama JV. MCP-1 is overexpressed in triple-negative breast cancers and drives cancer invasiveness and metastasis. Breast Cancer Research and Treatment. 2018;170(3):477-86.

30. Balogh KN, Templeton DJ, Cross JV. Macrophage Migration Inhibitory Factor protects cancer cells from immunogenic cell death and impairs anti-tumor immune responses. PloS one. 2018;13(6):e0197702-e.

31. Conroy H, Mawhinney L, Donnelly SC. Inflammation and cancer: macrophage migration inhibitory factor (MIF)--the potential missing link. QJM. 2010;103(11):831-6.

32. Rupertus K, Sinistra J, Scheuer C, Nickels RM, Schilling MK, Menger MD, et al. Interaction of the chemokines I-TAC (CXCL11) and SDF-1 (CXCL12) in the regulation of tumor angiogenesis of colorectal cancer. Clinical \& Experimental Metastasis. 2014;31(4):447-59.

33. Ejaeidi AA, Craft BS, Puneky LV, Lewis RE, Cruse JM. Hormone receptor-independent CXCL10 production is associated with the regulation of cellular factors linked to breast cancer progression and metastasis. Experimental and Molecular Pathology. 2015;99(1):163-72.

34. Eubank TD, Roberts RD, Khan M, Curry JM, Nuovo GJ, Kuppusamy P, et al. Granulocyte macrophage colony-stimulating factor inhibits breast cancer growth and metastasis by invoking an antiangiogenic program in tumor-educated macrophages. Cancer research. 2009;69(5):2133-40.

35. Johnson-Holiday C, Singh R, Johnson E, Singh S, Stockard CR, Grizzle WE, et al. CCL25 mediates migration, invasion and matrix metalloproteinase expression by breast cancer cells in a CCR9dependent fashion. Int J Oncol. 2011;38(5):1279-85.

36. Sarvaiya PJ, Guo D, Ulasov I, Gabikian P, Lesniak MS. Chemokines in tumor progression and metastasis. Oncotarget. 2013;4(12):2171-85.

37. Fortner RT, Sarink D, Schock H, Johnson T, Tjønneland A, Olsen A, et al. Osteoprotegerin and breast cancer risk by hormone receptor subtype: a nested case-control study in the EPIC cohort. BMC medicine. 2017;15(1):26-.

38. Martínez-Reza I, Díaz L, García-Becerra R. Preclinical and clinical aspects of TNF- $\alpha$ and its receptors TNFR1 and TNFR2 in breast cancer. J Biomed Sci. 2017;24(1):90-. 
medRxiv preprint doi: https://doi.org/10.1101/2020.06.09.20127068; this version posted June 11, 2020. The copyright holder for this preprint (which was not certified by peer review) is the author/funder, who has granted medRxiv a license to display the preprint in perpetuity.

It is made available under a CC-BY-NC-ND 4.0 International license .

39. Hung C-S, Wang S-C, Yen Y-T, Lee T-H, Wen W-C, Lin R-K. Hypermethylation of CCND2 in Lung and Breast Cancer Is a Potential Biomarker and Drug Target. International journal of molecular sciences. 2018;19(10):3096.

40. Kim S, Shore DL, Wilson LE, Sanniez EI, Kim JH, Taylor JA, et al. Lifetime use of nonsteroidal anti-inflammatory drugs and breast cancer risk: results from a prospective study of women with a sister with breast cancer. BMC Cancer. 2015;15:960.

41. Moris D, Kontos M, Spartalis E, Fentiman IS. The Role of NSAIDs in Breast Cancer Prevention and Relapse: Current Evidence and Future Perspectives. Breast Care. 2016;11(5):339-44.

42. Orlowski RZ, Kuhn DJ. Proteasome Inhibitors in Cancer Therapy: Lessons from the First Decade. Clinical Cancer Research. 2008;14(6):1649-57.

43. Skaar JR, Pagan JK, Pagano M. Mechanisms and function of substrate recruitment by F-box proteins. Nature Reviews Molecular Cell Biology. 2013;14(6):369-81.

44. Glickman MH, Ciechanover A. The Ubiquitin-Proteasome Proteolytic Pathway: Destruction for the Sake of Construction. Physiological Reviews. 2002;82(2):373-428.

45. Barnes BJ, Kellum MJ, Field AE, Pitha PM. Multiple regulatory domains of IRF-5 control activation, cellular localization, and induction of chemokines that mediate recruitment of T lymphocytes. Molecular and cellular biology. 2002;22(16):5721-40.

46. Massimino M, Vigneri P, Fallica M, Fidilio A, Aloisi A, Frasca F, et al. IRF5 promotes the proliferation of human thyroid cancer cells. Molecular cancer. 2012;11:21-.

47. Martin M. Cutadapt removes adapter sequences from high-throughput sequencing reads. 2011. 2011;17(1):3.

48. Colaprico A, Silva TC, Olsen C, Garofano L, Cava C, Garolini D, et al. TCGAbiolinks: an R/Bioconductor package for integrative analysis of TCGA data. Nucleic Acids Research. 2015;44(8):e71-e.

\section{Figure legends}

Figure 1. The FBXL8 mRNA level is significantly upregulated in human breast carcinoma tissues. To characterize the expression profiles of F-box family members in human breast cancer (BRCA), a retrospective study was performed by NGS-based RNA-Seq. Breast carcinoma tissues and the corresponding normal counterparts were characterized for their global mRNA profiles. (A) Clinicopathological parameters of five representative BRCA patient carcinoma tissue samples were studied. Red arrow highlights the upregulation of FBXL8. Clinicopathological information provided from 
medRxiv preprint doi: https://doi.org/10.1101/2020.06.09.20127068; this version posted June 11, 2020. The copyright holder for this preprint (which was not certified by peer review) is the author/funder, who has granted medRxiv a license to display the preprint in perpetuity.

It is made available under a CC-BY-NC-ND 4.0 International license .

medical records includes age, gender ( $F$, Female), pT (Primary Tumour), pN (pathologic lymph node status), pM (Distant Metastasis), etiology and staging of the patients by clinical tumor-node-metastasis. IDC, Invasive ductal carcinoma; ILC, Invasive lobular carcinoma; ER, estrogen receptor; PR, progesterone receptor. (B) Quantitative results from each patient. Each data point represents an EdgeR normalized count for FBXL8 $\left({ }^{*}\right.$, FDR $\left.<0.05\right)$. (C) Box-whisker plot of the FBXL8 mRNA in TCGA database. Vertical lines, box and horizontal white line correspond to min-max range, 25-75th percentile range and median, respectively. Data are reported as normalized count as provided in the TCGA level 3 data $\left(^{* *}, p<0.01\right)$. (D) The sequence alignment of FBXL8 in mammalian species. Comparative amino acid sequence alignment of FBXL8 from human (NP_060848.2), chimpanzee (XP_511023.2), pig (XP_020949705.1), mouse (NP_056636.2), rat (NP_001102598.1), bovine (NP_001070405.1) and beaver (XP_020031370.1) shows conservation of residues among all species (color highlights). Clustal Omega software was used for multiple sequence alignment.

Figure 2. FBXL8 and key ubiquitin components are upregulated in human primary BRCA tissues. To clarify the potential of FBXL8-associated ubiquitination, analyses were performed by both qRT-PCR (A and B) and IHC (C). In total, 32 paired primary tissues are examined by qRT-PCR ( $n=64)$. (A) FBXL8 shows significant overexpression in carcinoma tissues, particularly in advanced stages $\left({ }^{* *}, p<0.01\right)$. (B) SAG, a key component of SCF E3 ubiquitin ligase, was also elevated in BRCA tissues throughout all disease stages. FBXL8 or SAG gene was normalized against GAPDH housekeeping gene. Data are representative of means $\pm S D(n=3) .{ }^{* *}, p<0.01 ;{ }^{* * *}$, p<0.001. (C) H\&E and immunohistochemistry (IHC) staining. Inflammatory cell infiltration is indicated with yellow arrows. Protein expression levels of FBXL8 and 
medRxiv preprint doi: https://doi.org/10.1101/2020.06.09.20127068; this version posted June 11, 2020. The copyright holder for this preprint (which was not certified by peer review) is the author/funder, who has granted medRxiv a license to display the preprint in perpetuity.

It is made available under a CC-BY-NC-ND 4.0 International license .

ubiquitin are examined in both normal $(n=30)$ and carcinoma $(n=30)$ breast tissues. The corresponding quantitative results of FBXL8 and ubiquitin in IHC are shown in panels (D) and (E), respectively. Consistent with the mRNA levels, the FBXL8 proteins are significantly upregulated in breast carcinoma tissues, as the cancer advanced into the later stages. Ubiquitin is also upregulated significantly in carcinoma tissues. The corresponding clinicopathological information for qRT-PCR analysis and IHC are shown in Supplementary Figure S1 and Supplementary Figure S2, respectively. Brown color indicates DAB dye-stained proteins of interest. Scale bar is $100 \mu \mathrm{m}$, shown as the red color line $(-) .{ }^{* * *}, p<0.001$.

Figure 3. FBXL8 plays a critical anti-apoptotic role in BRCA. To elucidate the functional role of FBXL8 in breast carcinoma, we analyzed various human breast cancer cell lines: MCF-7 and MDA-MB231, compared to a non-cancer control breast cell line, MCF10A. (A) qRT-PCR shows the endogenous levels of FBXL8 mRNA in MCF7 and MDA-MB231, compared to MCF10A cells. FBXL8 mRNA is significantly upregulated in breast carcinoma cells. (B) qRT-PCR analysis was used to measure the RNAi efficacy. Optimized transfection efficacy with FBXL8-specific siRNA is shown in both MCF7 and MBA-MD231 cells. Knockdown efficiency was optimal at $24 \mathrm{~h}$ where, up to $95 \%$ loss of FBXL8 mRNA was achieved in both cell lines, compared to controls using PBS and scrambled siRNA $\left({ }^{* * *}, p<0.001\right)$. The cell viability of FBXL8 knocked down BRCA cell lines was significantly reduced as shown by: (C) MTT and (D) CTB assays. For each time point, cell counts were normalized to the corresponding PBStreated controls. (E) Alamar Blue or (F) Trypan Blue exclusion tests showed significant reduction in cell proliferation. (G) Annexin $\mathrm{V}$ and 7-aminoactinomycin (7-AAD) double staining was conducted to examine early apoptosis (AnnexinV ${ }^{+} / 7 A A^{-}$, red box). (H) FBXL8-siRNA knockdown of MCF7 and MDA-MB231 cells underwent apoptosis via 
medRxiv preprint doi: https://doi.org/10.1101/2020.06.09.20127068; this version posted June 11, 2020. The copyright holder for this preprint (which was not certified by peer review) is the author/funder, who has granted medRxiv a license to display the preprint in perpetuity.

It is made available under a CC-BY-NC-ND 4.0 International license .

activation of Caspases -9 and -3 , suggesting that presence of FBXL8 is pivotal to antiapoptosis in BRCA. Representative histograms of apoptosis assay are shown in Supplementary Figure S3. Data are means $\pm S D(n=3) .{ }^{* * *}, p<0.001$

Figure 4. Knockdown of FBXL8 effectively suppressed BRCA migration and invasion. Cell migration assay was performed for: (A) MCF7 and (B) MDA-MB231 cells. Corresponding quantitative results are shown in (C) and (D). Compared with control siRNA, FBXL8 siRNA-treated cells showed significant decrease in the rate of migration. For each treatment, the migration rate (\% gap closure) was normalized to the corresponding $0 \mathrm{~h}$ time point controls. Cell invasion assay and corresponding quantitative results are shown in $(\mathbf{E})$ and $(\mathbf{F})$, respectively. We showed that FBXL8knockdown effectively reduced cell invasion. Data are representative of means $\pm S D$ $(\mathrm{n}=3) .{ }^{* * *}, p<0.001$

Figure 5. Knockdown of FBXL8 suppressed the production of inflammatory cytokines, chemokines and growth factors in breast carcinoma cells. Culture supernatants collected from cells treated with FBXL8-specific RNAi for $48 \mathrm{~h}$, were analyzed for secreted tumorigenic factors using human cytokine array and ELISA. (A) Compared to control siRNA, treatment of FBXL8-specific RNAi significantly reduced the production of cancer-promoting factors, including MCP-1, I-TAC, TECK, CTACK, MIF, GM-CSF, NT-3, FGF-6, Angiogenin, EGFR, ICAM-1, Fas, DtK and TRALIR3. In contrast, FBXL8 knockdown elevated the secretion of pro-tumorigenic IL-6R and TNFR1 in BRCA. Osteoprotegerin (OPG) shows opposite trend in MCF7 and MDAMB231 cells. Blue boxes: down-regulation and red boxes: up-regulation of factors secreted by FBXL8-knockdowned cells. The numbers next to the blue/red boxes indicate: (1) Angiogenin, (2) FGF-6, (3) GM-CSF, (4) MCP-1, (5) NT-3, (6) CTACK, (7) 
medRxiv preprint doi: https://doi.org/10.1101/2020.06.09.20127068; this version posted June 11, 2020. The copyright holder for this preprint (which was not certified by peer review) is the author/funder, who has granted medRxiv a license to display the preprint in perpetuity.

It is made available under a CC-BY-NC-ND 4.0 International license .

DtK, (8) EGFR, (9) Fas, (10) ICAM-1, (11) IL-6R, (12) I-TAC, (13) MIF, (14) OPG, (15)

TNFR1, (16) TECK and (17) TRALIR3. The array membranes are spotted in duplicate.

(B) ELISA confirmed differential quantities of GM-CSF, MCP-1, CTACK, EGFR, ICAM-

1, I-TAC, MIF and TECK secreted from MCF7 and MDA-MB231 cells when FBXL8 was knocked down (blue bars). Data are representative of means $\pm \operatorname{SD}(n=3) .{ }^{* \star} P<0.01$, ${ }^{* * *} P<0.001$.

Figure 6. FBXL8 pulled down CCND2 and IRF5, and knockdown of FBXL8 accumulated CCND2 and IRF5 protein levels in BRCA cells. To clarify the potential of CCND2 and IRF5 in primary BRCA tissues, retrospective analyses were performed by IHC (A-C) and NGS-based RNA-Seq (D, E), and from TCGA database $(F, G) .(A)$ immunofluorescence staining of CCND2 and IRF5. Protein expression levels of CCND2 and IRF5 are examined in both normal $(n=30)$ and carcinoma $(n=30)$ breast tissues. The corresponding quantitative results of CCND2 and IRF5 in IHC are shown in panels (B) and (C), respectively. (D and E) Quantitative results from each patient. Each data point represents a log2 fold change value for CCND2 and IRF5 ( ${ }^{*}$, FDR $<0.05$ ). (F and $\mathbf{G})$ Box-whisker plot showing the transcript levels of CCND2 and IRF5 in TCGA database, respectively. Vertical lines, box and horizontal white line correspond to min-max range, 25-75th percentile range and median, respectively. Data are reported as normalized count as provided in the TCGA level 3 data $\left({ }^{* *}\right.$, $p<0.01)$. The corresponding clinicopathological information for $\mathrm{IHC}$ are shown in Supplementary Figure S2. Brown color indicates DAB dye-stained protein of interest. Scale bar is $50 \mu \mathrm{m}$, shown as the red color line (-). (H) Co-IP of of FBXL8 and CCND2 (or IRF5) in BRCA cells; total cell lysates were immunoprecipitated with anti-FBXL8 (or control anti-IgG $2 \mathrm{~b}$ ) antibody, separated by $10 \%$ SDS-PAGE, immunoblotted and probed with FBXL8, CCND2 or IRF5 antibodies. (I) To confirm whether CCND2 and IRF5 are 
medRxiv preprint doi: https://doi.org/10.1101/2020.06.09.20127068; this version posted June 11, 2020. The copyright holder for this preprint (which was not certified by peer review) is the author/funder, who has granted medRxiv a license to display the preprint in perpetuity.

It is made available under a CC-BY-NC-ND 4.0 International license .

regulated by FBXL8-dependent protein degradation, FBXL8 RNAi was performed in MCF7 and MDA-MB231 cells, followed by immunoblotting analysis. Tubulin was used as a loading control for immunoblotting.

Figure 7. A hypothetical model illustrating how FBXL8 attenuates anti-cancer CCND2 and IRF5 factors, upregulates pro-tumorigenic cytokines, suppresses apoptosis and promotes metastasis potential in BRCA. FBXL8, a novel SCF E3 ubiquitin ligase, plays a key role in anti-apoptosis in BRCA. (A) Knockdown of FBXL8 increased expression of cancer suppressors CCND2 and IRF5, thus inhibiting cell growth and proliferation in BRCA, driven by: (i) increase in early apoptosis, (ii) activation of Caspase- 9 and -3 , and (iii) inhibition of the production of cancer-promoting cytokines, including MCP-1, I-TAC, TECK, CTACK, MIF, GM-CSF, NT-3, FGF-6, Angiogenin, ICAM-1, DtK and EGFR. Therefore, FBXL8 promotes pro-tumorigenic microenvironment, contributing to BRCA metastasis and progression. (B) FBXL8 interacts and downregulates cancer suppressors CCND2 and IRF5 via protein degradation system. Hence, upregulated FBXL8 in BRCA causes the reduction of CCND2 and IRF5 proteins, and leads to dysregulated cell proliferation, immune response and metastatic potential of BRCA cells. 
medRxiv preprint doi: https://doi.org/10.1101/2020.06.09.20127068; this version posted June 11, 2020. The copyright holder for this preprint (which was not certified by peer review) is the author/funder, who has granted medRxiv a license to display the preprint in perpetuity.

Figure 1. The FBXL8 mRNA level is significantly upregulated in human breast carcinoma tissues.

\begin{tabular}{|c|c|c|c|c|c|}
\hline Patient & 1 & 2 & 3 & 4 & 5 \\
\hline Diagnosis & IDC & IDC & IDC & ILC & IDC \\
\hline H istologic type & IDC & IDC & IDC & ILC & IDC \\
\hline Histologic grade & 2 & 2 & 3 & 2 & 3 \\
\hline $\mathrm{pT}$ & Tle & $\mathrm{T} 2$ & $\mathrm{~T} 2$ & T3 & $\mathrm{T3}$ \\
\hline pN & No & No & No & No & N3a \\
\hline $\mathrm{pM}$ & NA & NA & NA & NA & NA \\
\hline Stage & IA & IIA & IIA & IIB & IIIC \\
\hline ER & + & + & - & + & + \\
\hline PR & + & + & - & + & - \\
\hline HE R2 & $1+$ & 0 & $2+$ & $2+$ & $2+$ \\
\hline Ki67\# & $25 \%$ & $10 \%$ & $25 \%$ & $15 \%$ & $30 \%$ \\
\hline Age (year) & 69 & 38 & 59 & 69 & 59 \\
\hline Gender (M/F) & F & $F$ & $\mathbf{F}$ & $F$ & $F$ \\
\hline $\begin{array}{c}\text { F BXI8 Normal } \\
\text { (normalized counts) }\end{array}$ & 0.57 & 1.7 & 1.65 & 2.1 & 1.25 \\
\hline $\begin{array}{c}\text { FBXLS Tumor } \\
\text { (normalized counts) }\end{array}$ & $2.46^{\circ}$ & $4.85 \uparrow$ & $2.8 \uparrow$ & $7.48 \uparrow$ & $4.13 \uparrow$ \\
\hline
\end{tabular}

\# Ki67 is an intracellular marker for cell proliferation. Generally, in breast cancer, expression of $\mathrm{Ki} 67(\%)>14 \%$ is taken as "positive" and patients will advise go for chemotherapy.
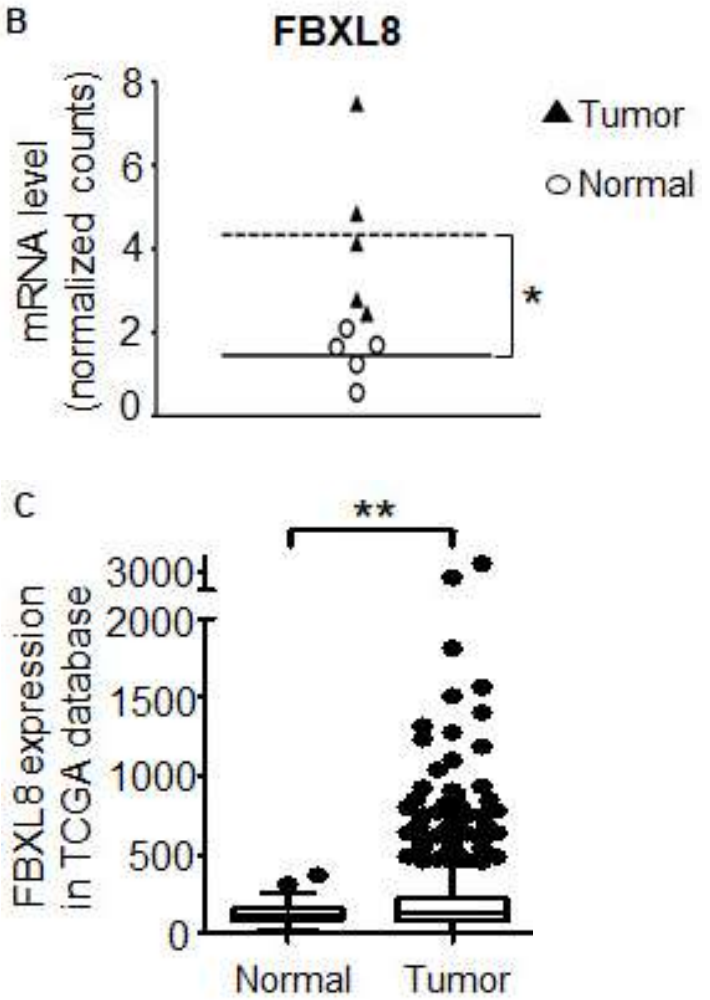

D

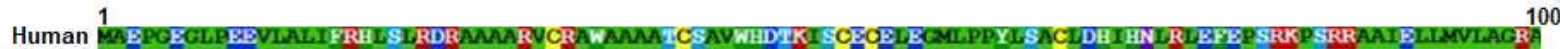

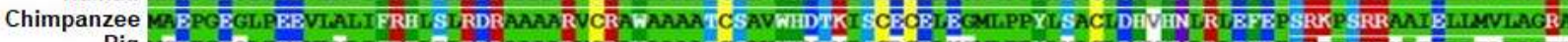

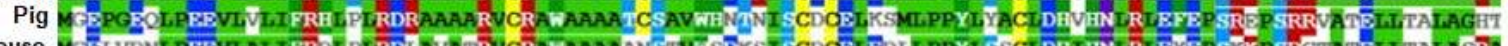

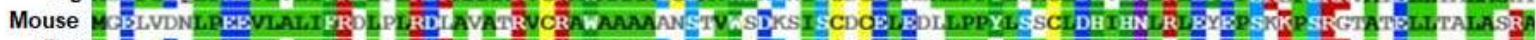

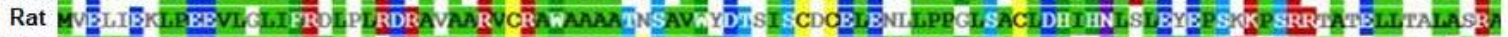

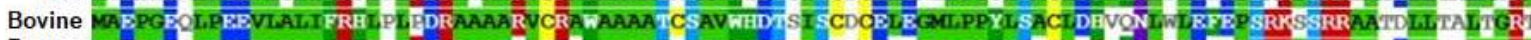

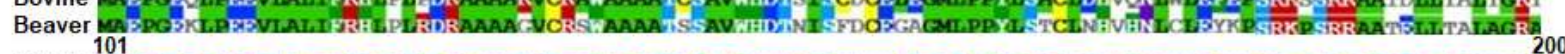

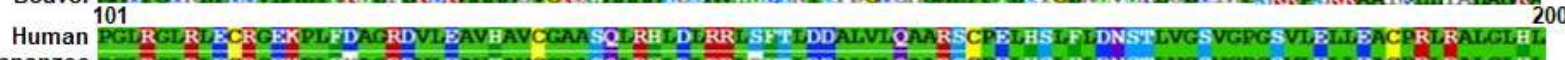

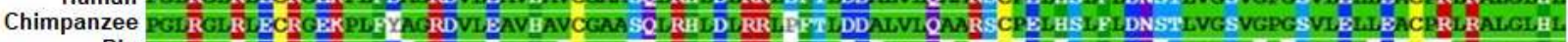

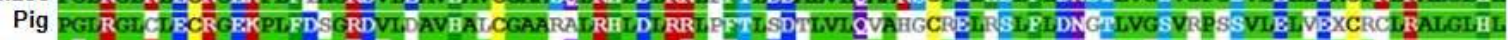

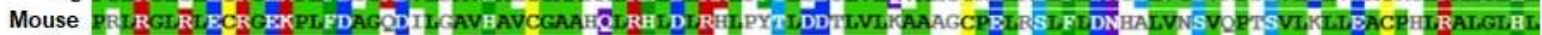

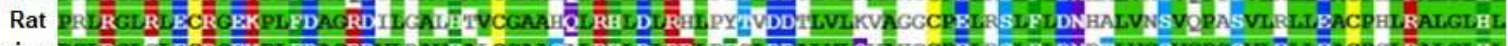

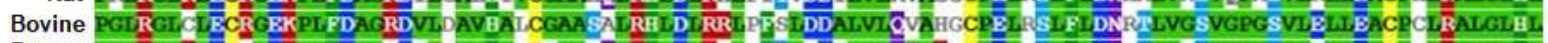

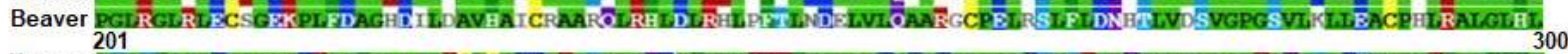

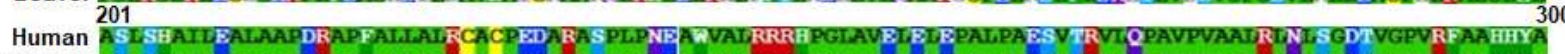

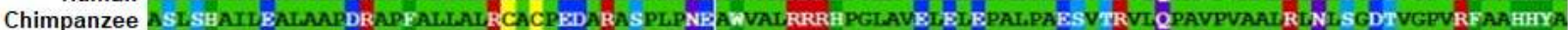

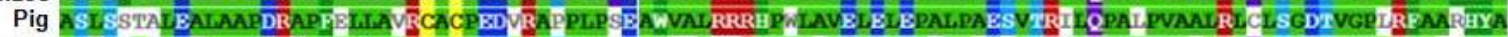

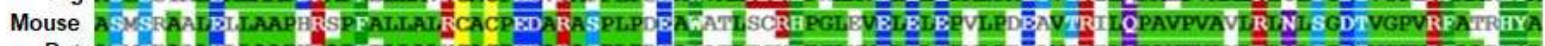

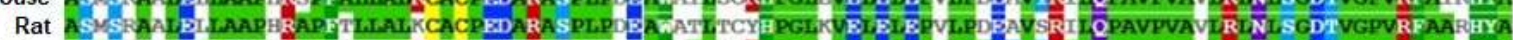

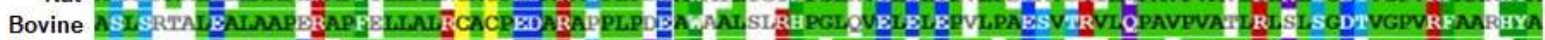

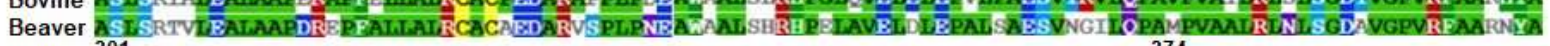

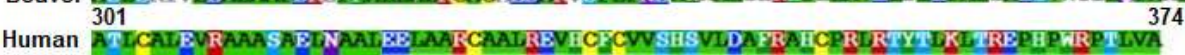

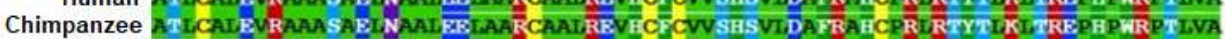

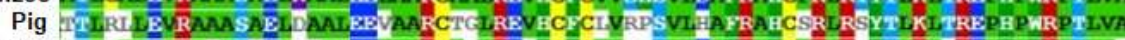

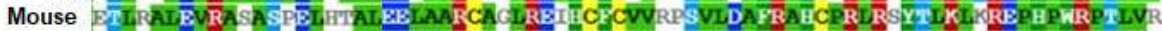

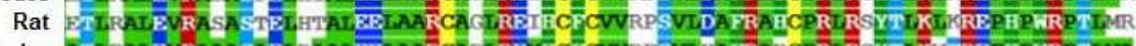

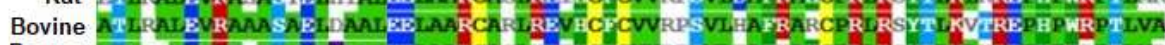

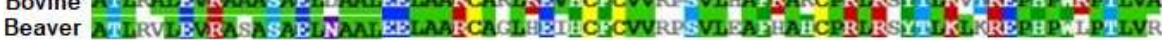


medRxiv preprint doi: https://doi.org/10.1101/2020.06.09.20127068; this version posted June 11, 2020. The copyright holder for this preprint (which was not certified by peer review) is the author/funder, who has granted medRxiv a license to display the preprint in perpetuity.

It is made available under a CC-BY-NC-ND 4.0 International license.

Figure 2. FBXL8 and key ubiquitin components are upregulated in human primary BRCA tissues.
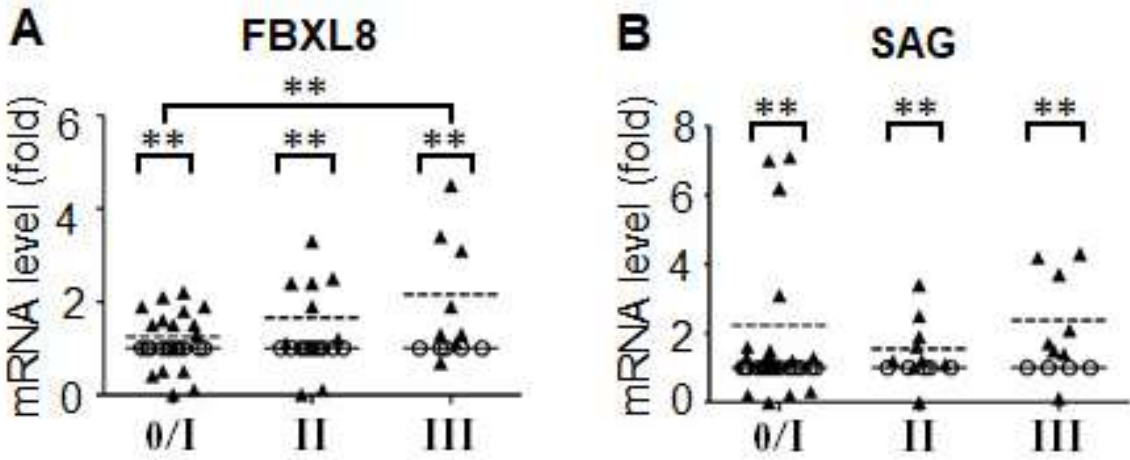

O Normal

$\Delta$ Carcinoma

C

Staging

0/lA

IA/llB

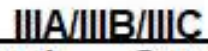
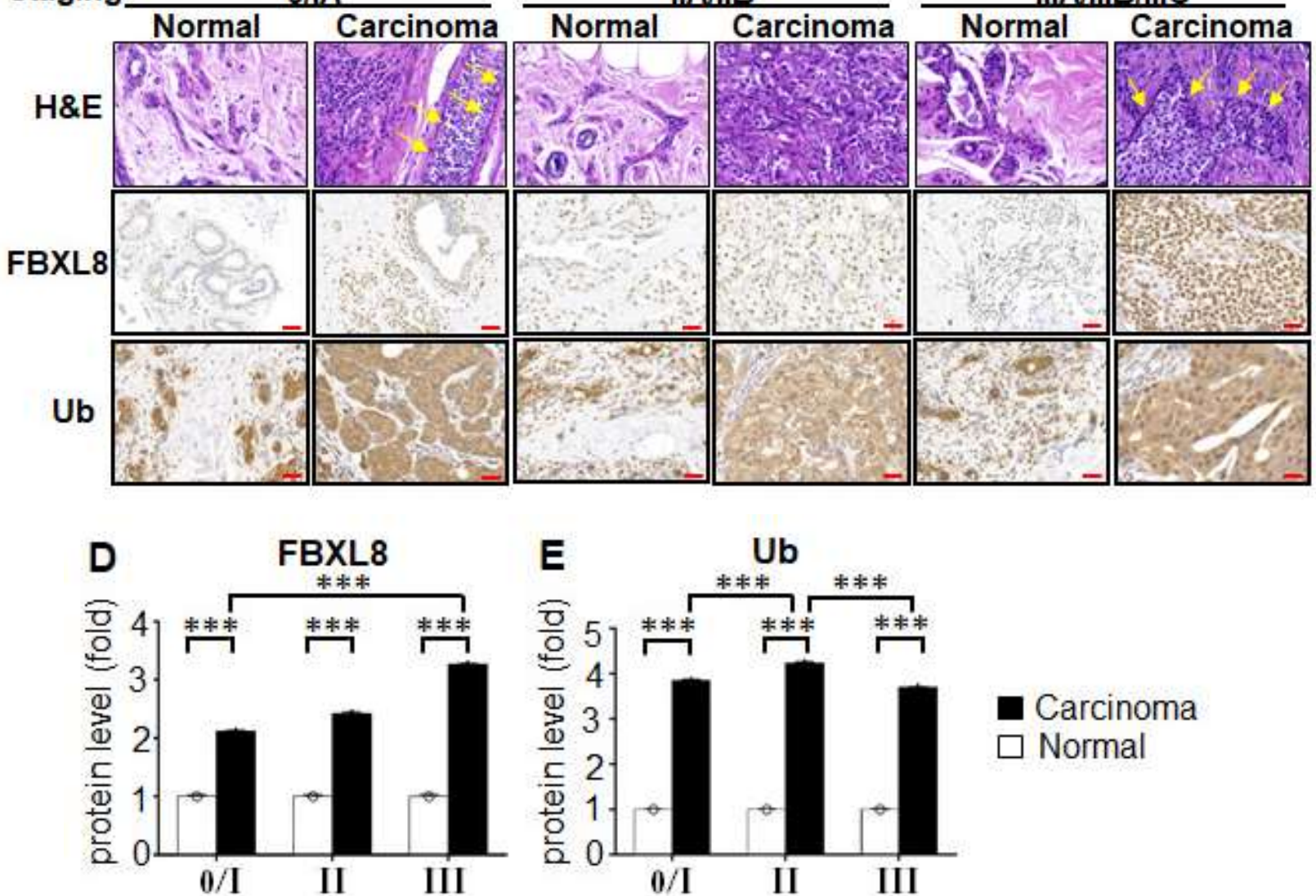

Carcinoma

Normal 
medRxiv preprint doi: https://doi.org/10.1101/2020.06.09.20127068; this version posted June 11, 2020. The copyright holder for this preprint (which was not certified by peer review) is the author/funder, who has granted medRxiv a license to display the preprint in perpetuity.

It is made available under a CC-BY-NC-ND 4.0 International license.

Figure 3. FBXL8 plays a critical anti-apoptotic role in BRCA.
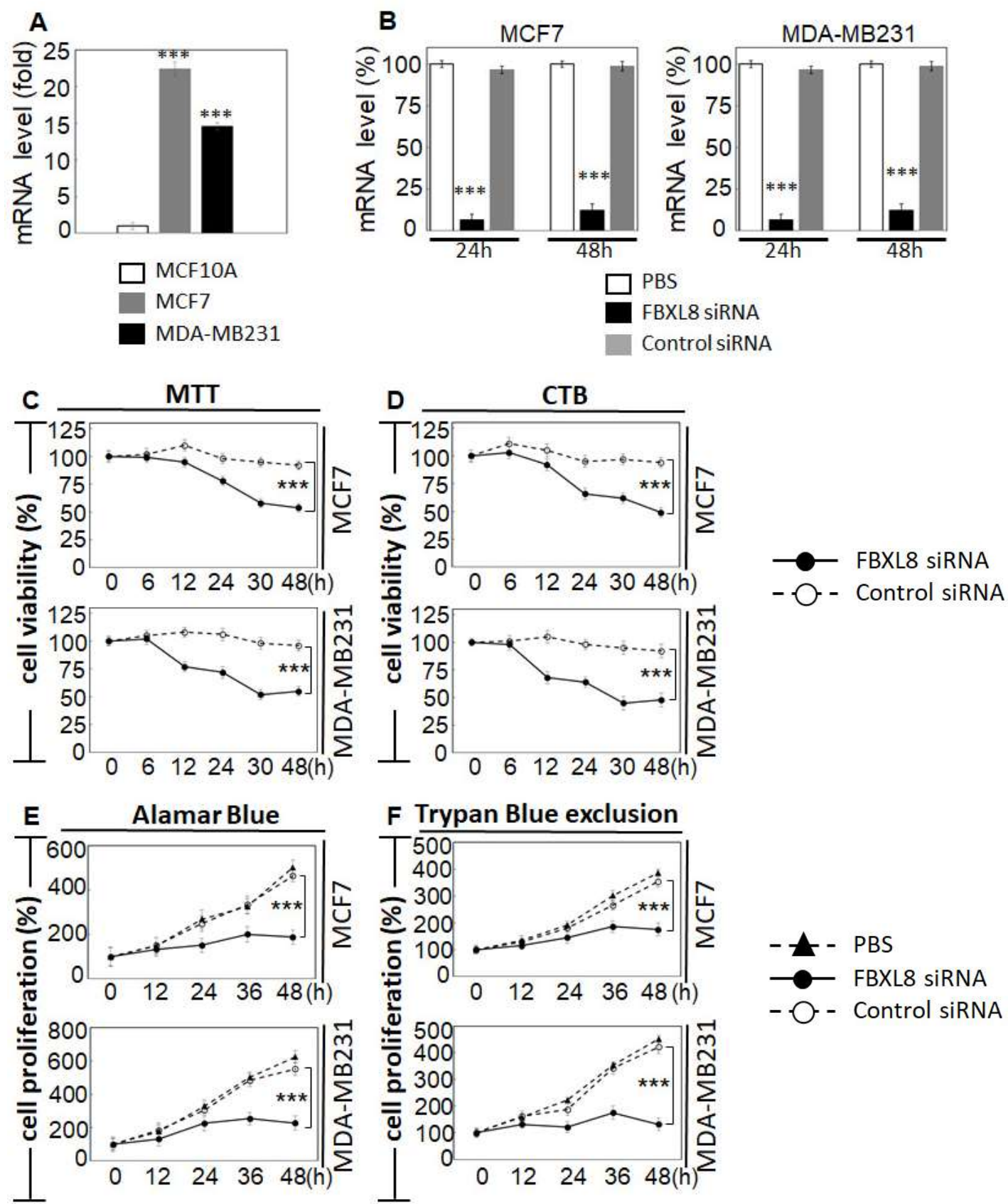

F Trypan Blue exclusion
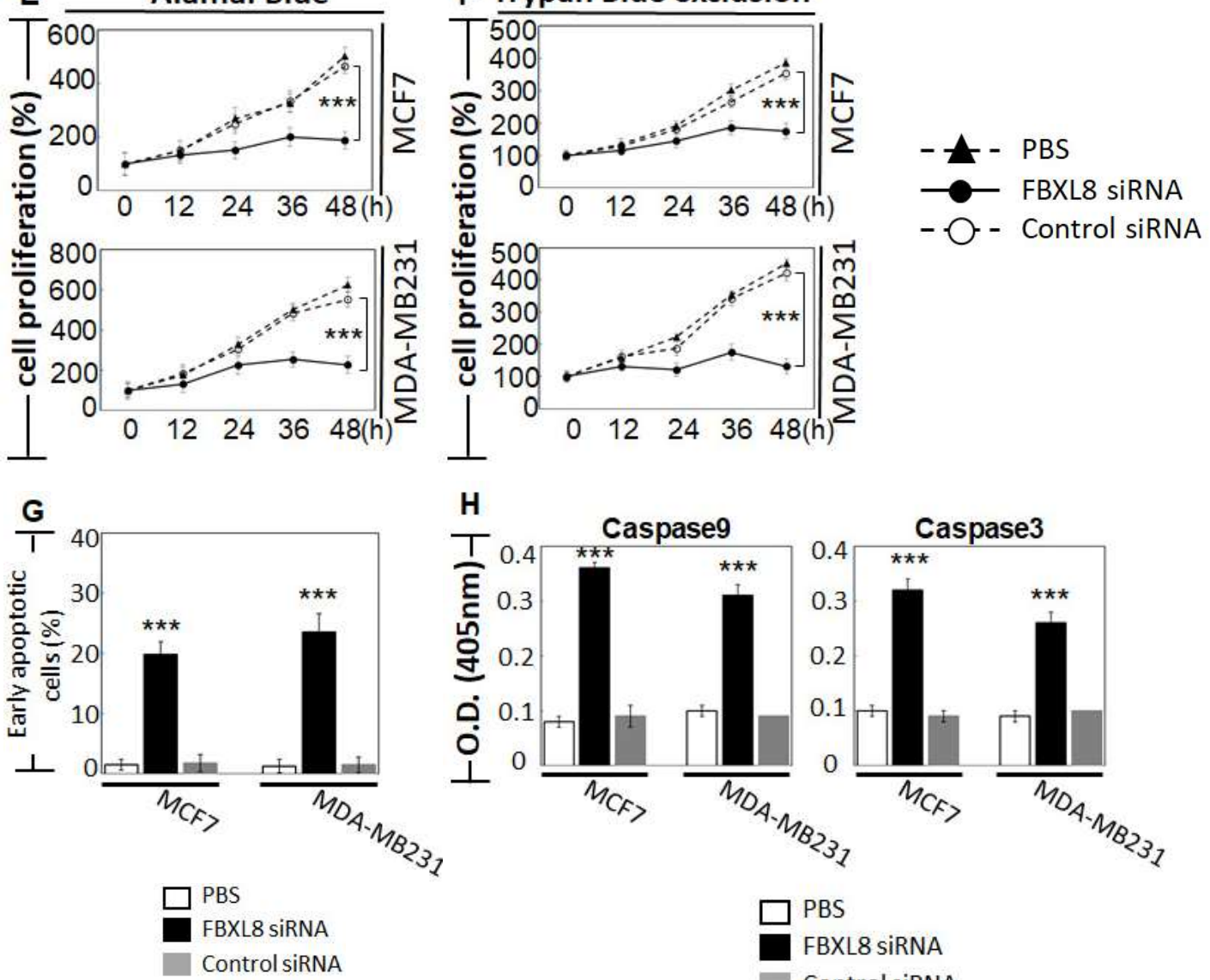

Control siRNA 
medRxiv preprint doi: https://doi.org/10.1101/2020.06.09.20127068; this version posted June 11, 2020. The copyright holder for this preprint (which was not certified by peer review) is the author/funder, who has granted medRxiv a license to display the preprint in perpetuity.

It is made available under a CC-BY-NC-ND 4.0 International license .

Figure 4. Knockdown of FBXL8 effectively suppressed BRCA migration and invasion.
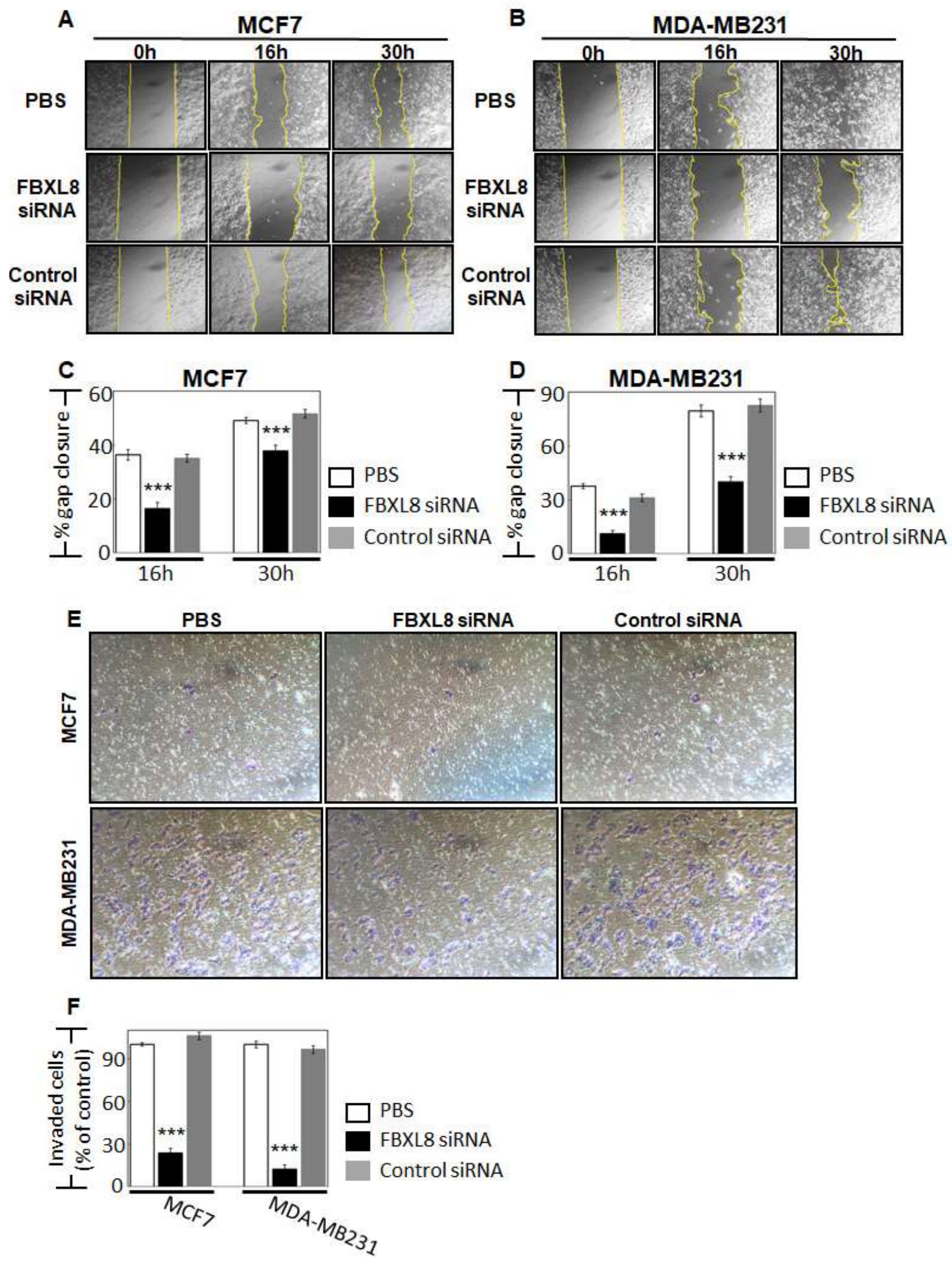
medRxiv preprint doi: https://doi.org/10.1101/2020.06.09.20127068; this version posted June 11, 2020. The copyright holder for this preprint (which was not certified by peer review) is the author/funder, who has granted medRxiv a license to display the preprint in perpetuity.

It is made available under a CC-BY-NC-ND 4.0 International license .

Figure 5. Knockdown of FBXL8 suppressed the production of inflammatory cytokines, chemokines and growth factors in breast carcinoma cells.

\section{A. Cytokine array}

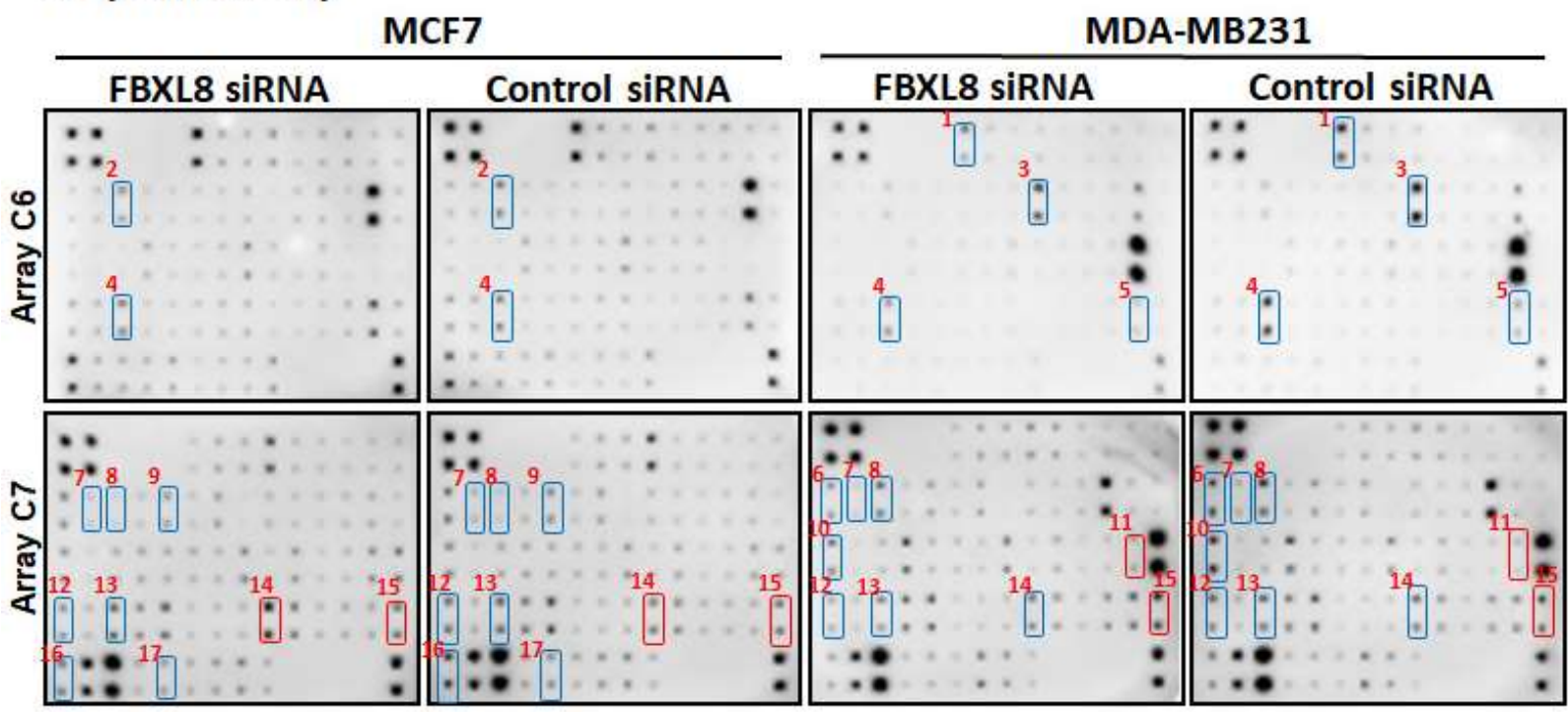

B. ELISA
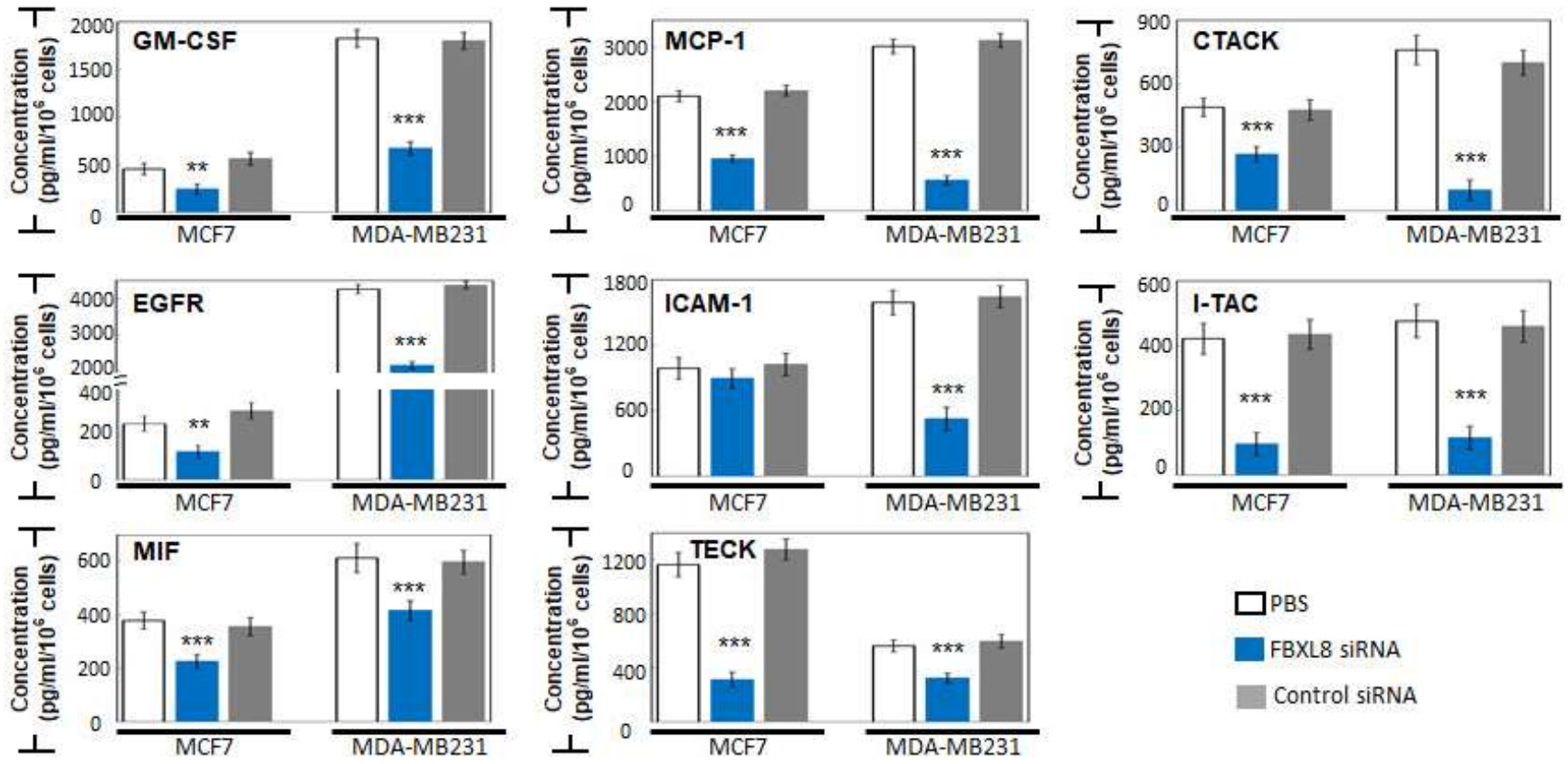

$\square$ PBS

FBXL8 SIRNA

Control siRNA 
medRxiv preprint doi: https://doi.org/10.1101/2020.06.09.20127068; this version posted June 11, 2020. The copyright holder for this preprint (which was not certified by peer review) is the author/funder, who has granted medRxiv a license to display the preprint in perpetuity.

It is made available under a CC-BY-NC-ND 4.0 International license.

Figure 6. FBXL8 pulled down CCND2 and IRF5, and knockdown of FBXL8 accumulated CCND2 and IRF5 protein levels in BRCA cells.

A
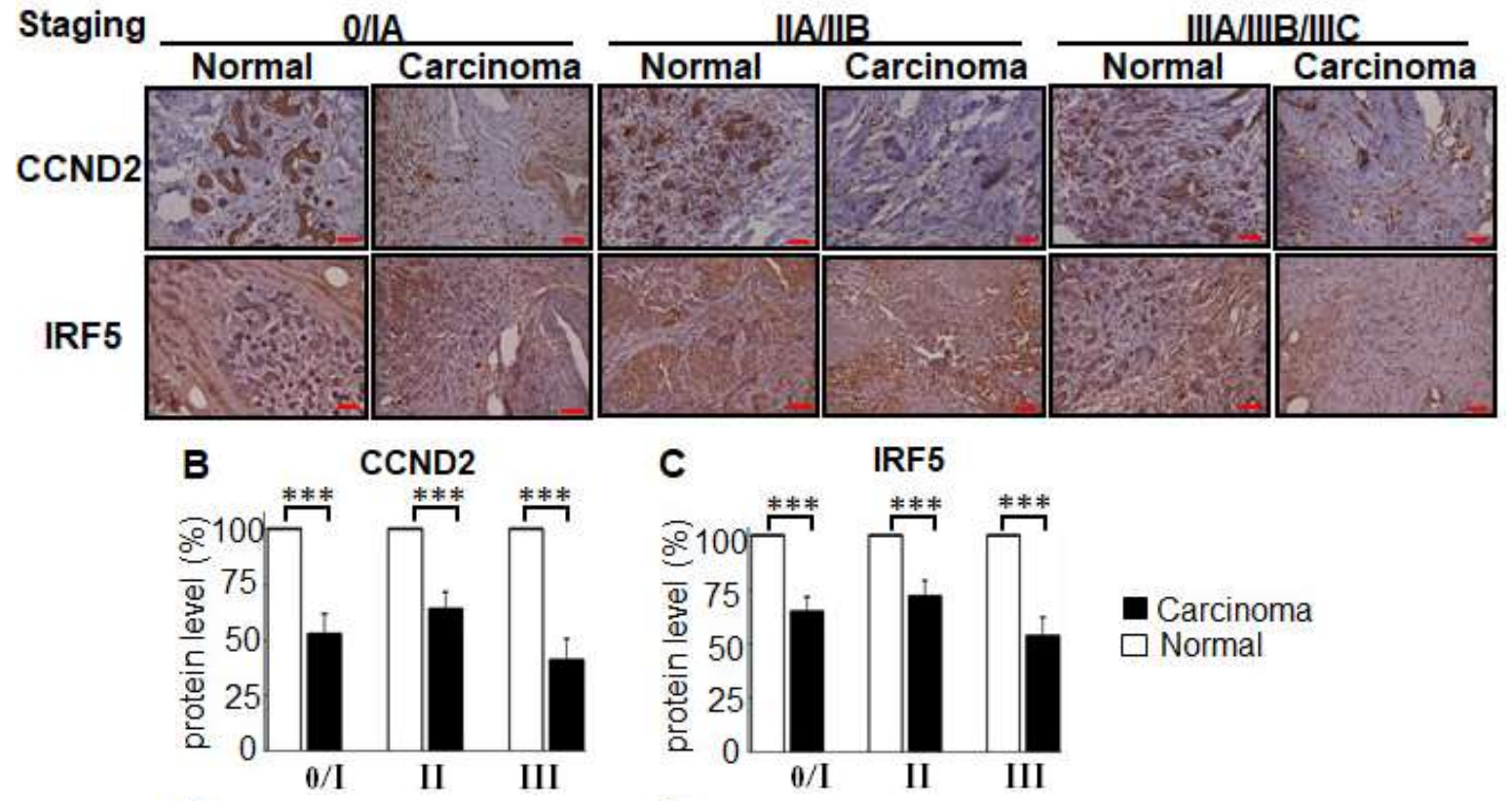

C IRF5
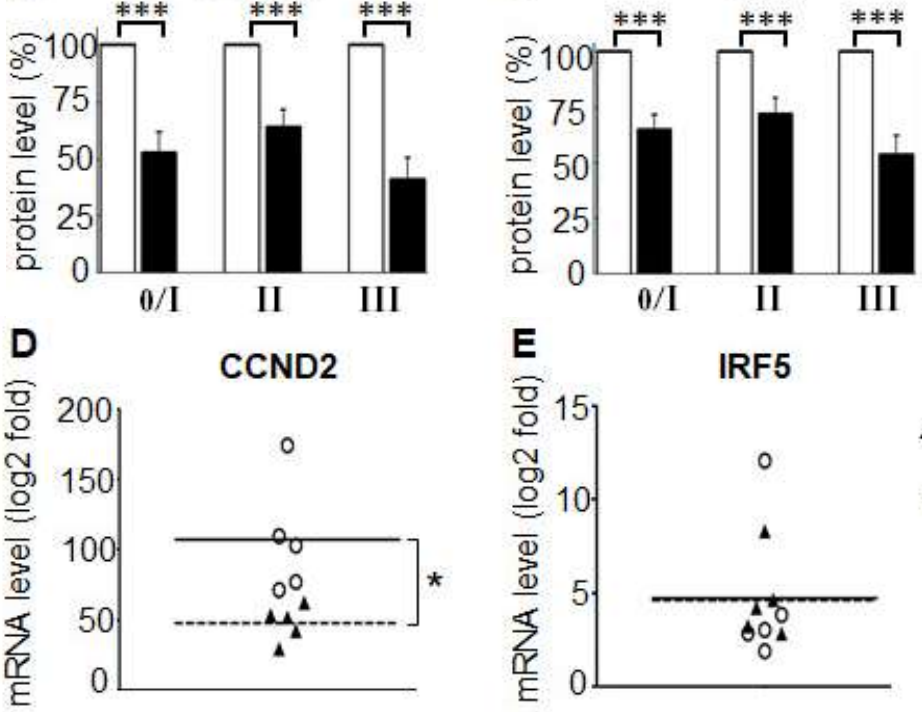

- Carcinoma

$\square$ Normal
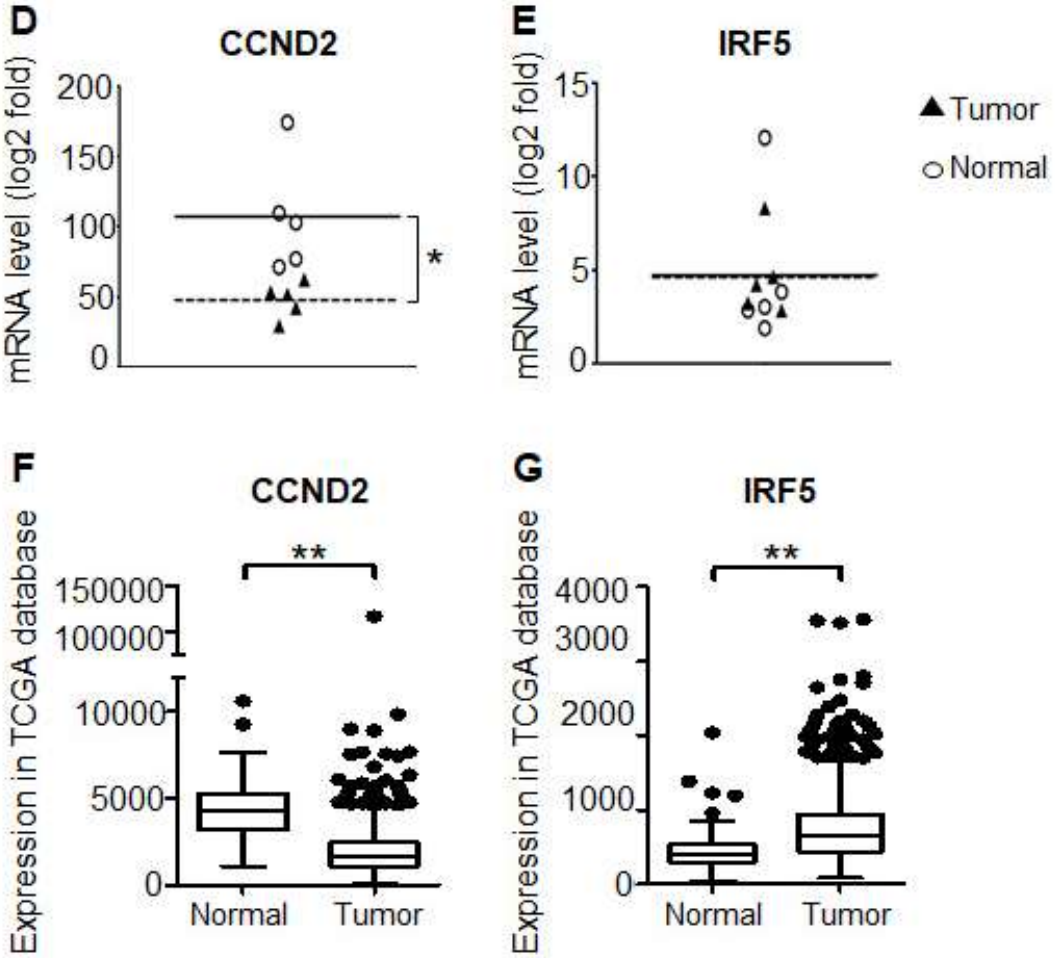

H
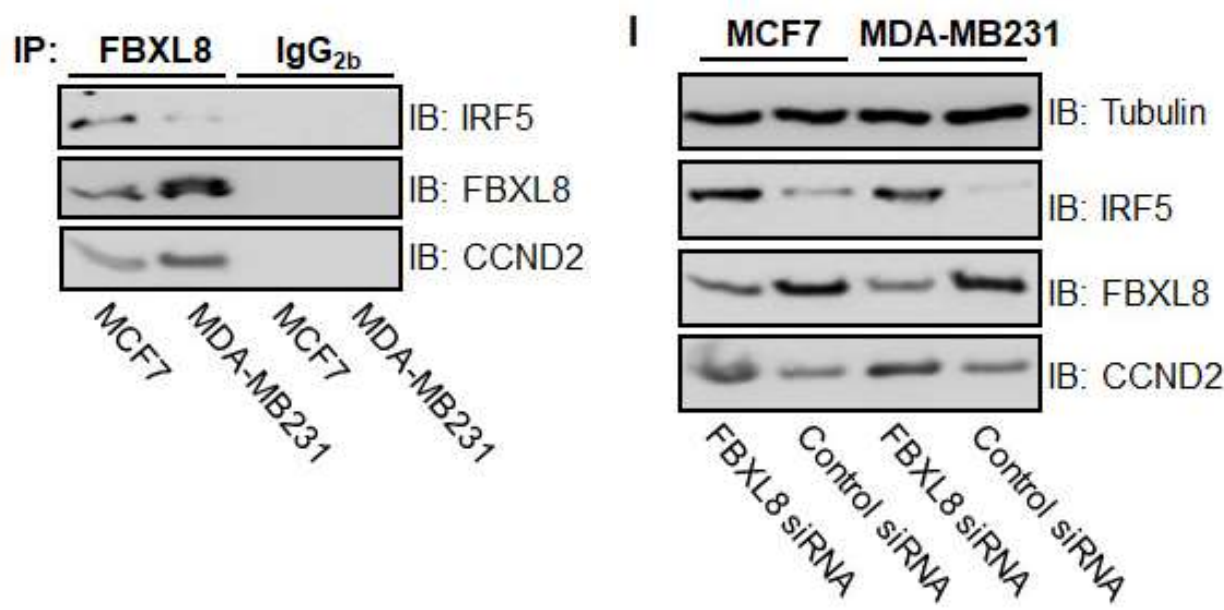
medRxiv preprint doi: https://doi.org/10.1101/2020.06.09.20127068; this version posted June 11, 2020. The copyright holder for this preprint (which was not certified by peer review) is the author/funder, who has granted medRxiv a license to display the preprint in perpetuity.

It is made available under a CC-BY-NC-ND 4.0 International license .

Figure 7. A hypothetical model illustrating how FBXL8 upregulates protumorigenic cytokines, suppresses apoptosis and promotes metastasis potential in BRCA.

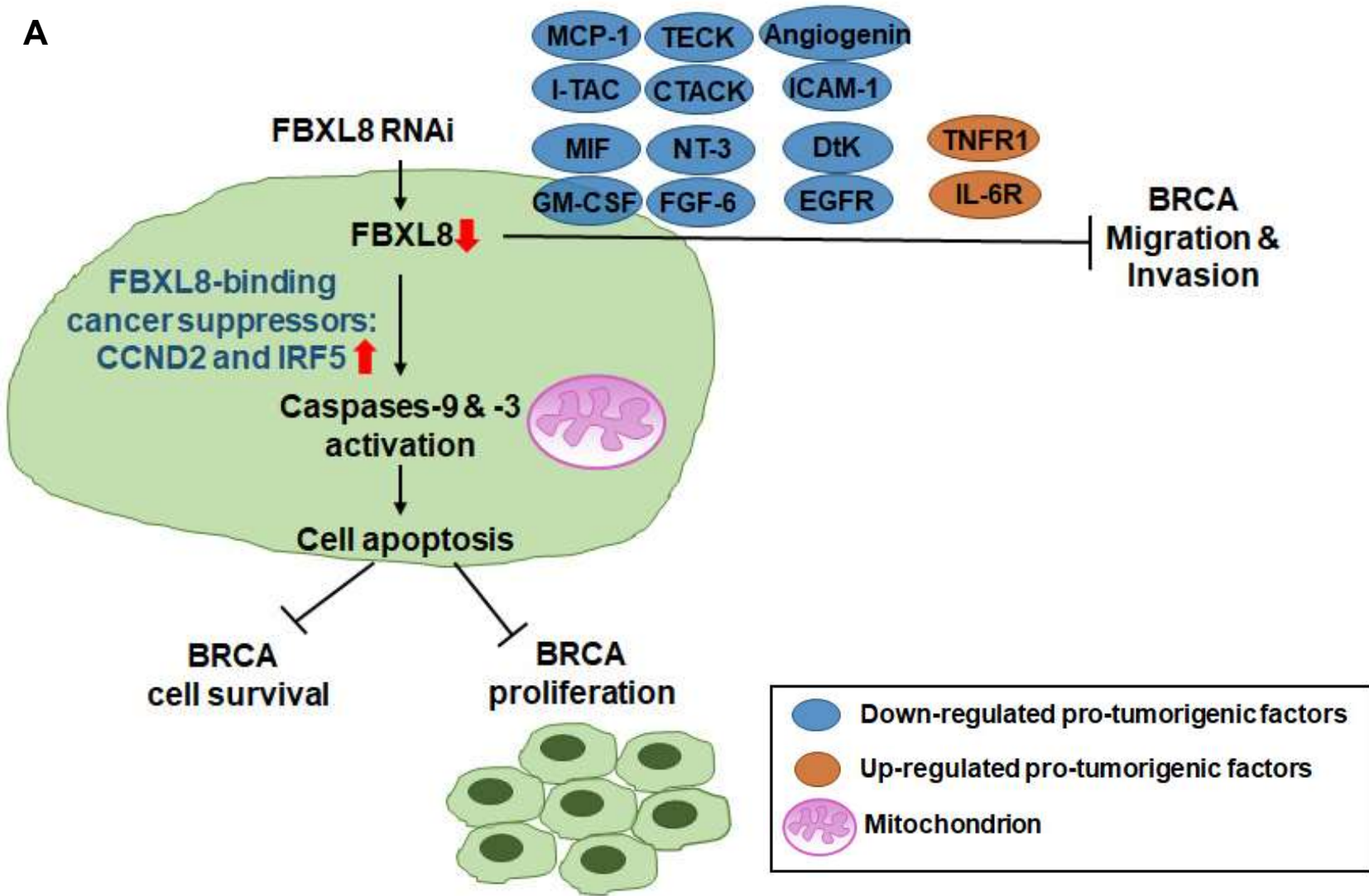

B

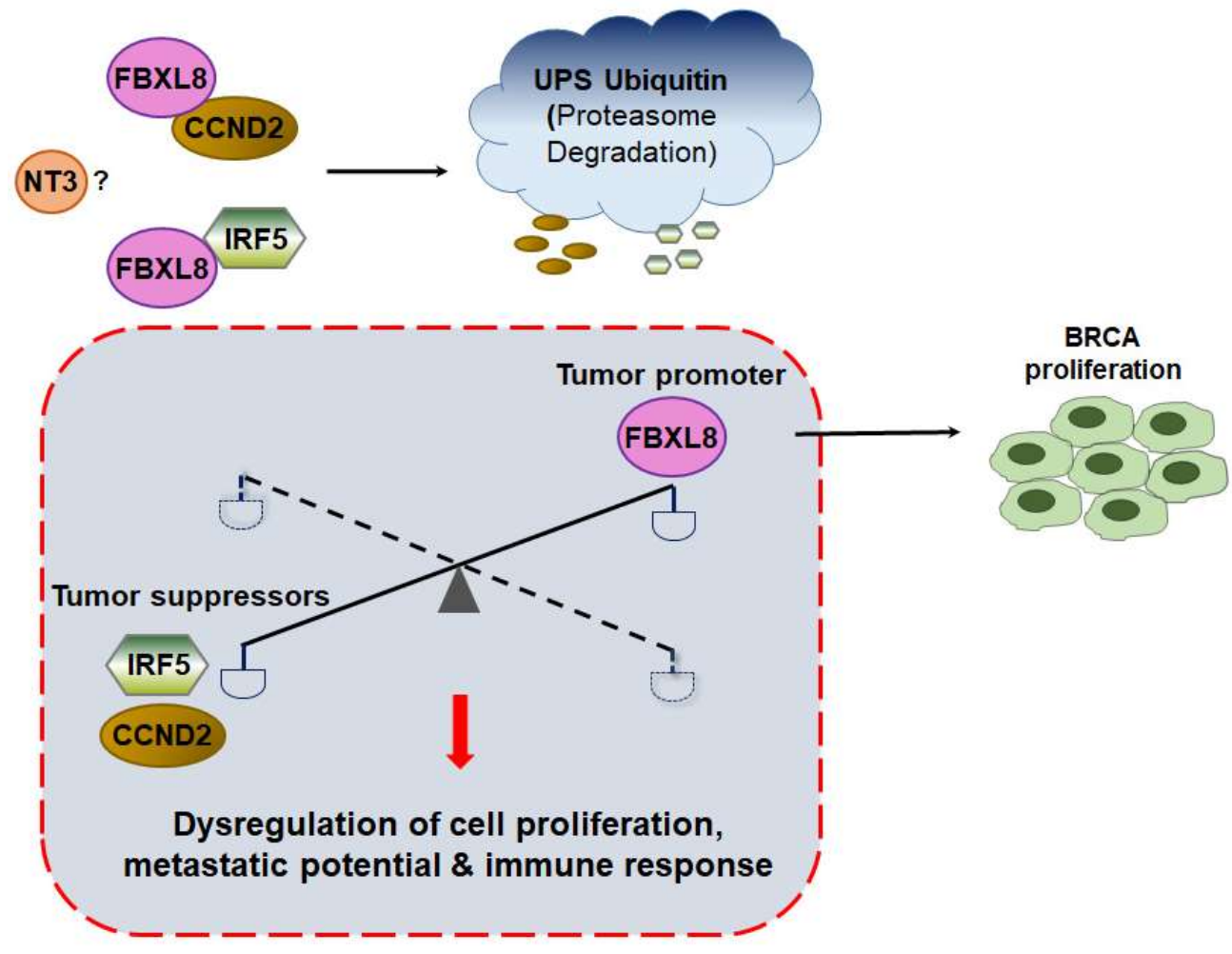

